Portland State University

PDXScholar

1978

\title{
The minorities of Czechoslovakia and Poland : of treaties and human nature
}

\author{
Bryant L. Larson \\ Portland State University
}

Follow this and additional works at: https://pdxscholar.library.pdx.edu/open_access_etds

Part of the Eastern European Studies Commons, and the European History Commons Let us know how access to this document benefits you.

\section{Recommended Citation}

Larson, Bryant L., "The minorities of Czechoslovakia and Poland : of treaties and human nature" (1978). Dissertations and Theses. Paper 2871.

https://doi.org/10.15760/etd.2865

This Thesis is brought to you for free and open access. It has been accepted for inclusion in Dissertations and Theses by an authorized administrator of PDXScholar. Please contact us if we can make this document more accessible: pdxscholar@pdx.edu. 
AN ABSTRACT OF THE THESIS OF Bryant L. Larson for the Master of Arts in History presented July 28, 1978.

Title: The Minorities of Czechoslovakia and Poland:

of Treaties and Human Nature.

APPROVED BY MEMBERS OF THE THESIS COMMITTEE:

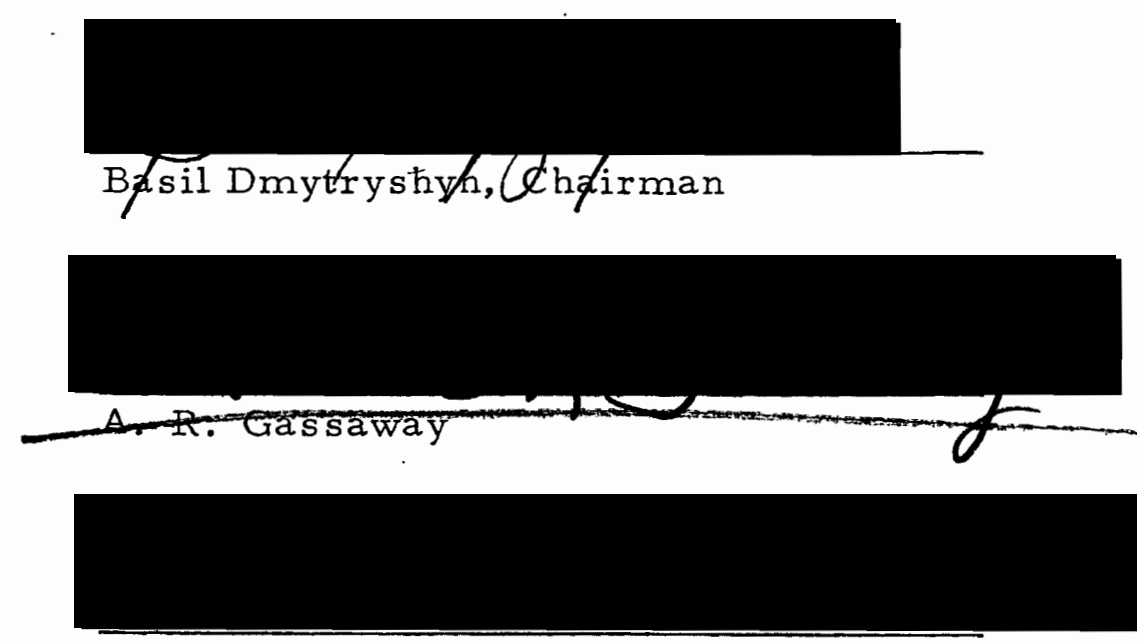

Charles A. LeGuin

Franklin C. West

The most explosive phenomenon of modern contemporary history has been the friction between the aspirations of "national minorities" and the ambitions of "ruling majorities." Strictly speaking, the problem is not new. It is as old as recorded history. Its intensity in recent times has been greatly stimulated by the 
demands of every ethnic group for an independent political existence; by the use of fair and foul means by the se groups to attain that goal; by rivalries among great and small powers that often stimulate false hopes and national aspirations; and by the successful emergence of many new states.

This thesis explores briefly two experimental cases, Czechoslovakia and Poland, where between 1919 and 1938, efforts were made to solve the "minority problem." This thesis consists of five basic parts: Chapter I, an introduction that defines or describes such concepts as nationalism, nation, state, and minority; Chapter II that succinctly presents backgrounds and problems of minorities in Czechoslovakia (Germans, Magyars, Ruthenians, and Jews), and Poland (Germans, Jews and Ukrainians); Chapter III that analyzes the provisions of the Minority Treaties prepared by the principal Allied Powers at the end of World War I to protect minority rights within $\mathrm{C} z e c h o s l o v a k i a$ and Poland; Chapter IV that examines the implementation and results of the planned protection of minority rights in Czechoslovakia and Poland between 1919 and 1938; and Appendices that illuminate the minority problem in the two states.

The conclusion of the thesis deals with five characteristics of human behavior and human relations that surfaced in Czechoslovakia and Poland between 1919 and 1938. The perception of 
nationality was the first revealed characteristic. The second was the need to recognize the importance of the acceptance factor in all assimilation objectives. The great difference, in the minds of the minorities, between equality and tolerance was a third characteristic. The fourth was the realization that time, by itself, does not solve the minority problem. The fifth and final revealed characteristic was the absolute need for humanitarianism at both leadership and local levels. By connecting the se five characteristics with the contemporary scene, the thesis contributes to greater interest in, and greater knowledge of, the continuing problem of the national minority. 
THE MINORITIES OF CZECHOSLOVAKIA AND POLAND: OF TREATIES AND HUMAN NATURE

by

BRYANT L. LARSON

A thesis submitted in partial fulfillment of the requirements for the degree of

MASTER OF ARTS

in

HISTORY

Portland State University

1978 
TO THE OFFICE OF GRADUATE STUDIES AND RESEARCH:

The members of the Committee approve the thesis of

Bryant L. Larson presented July 28, 1978.

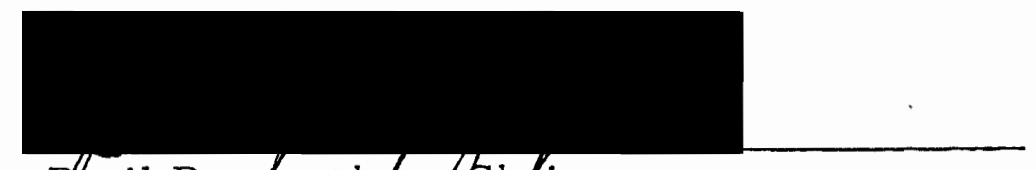

Dhasil Dmytryshyn, Cthairman

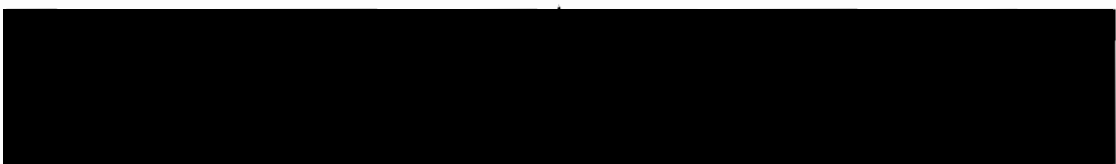

A. R. Gassaway

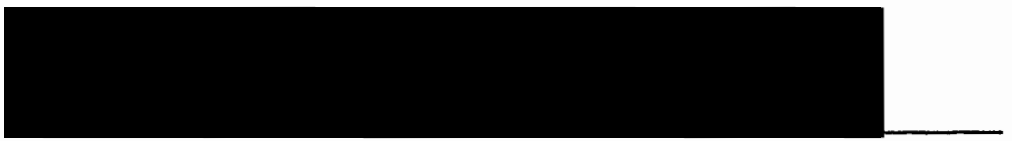

Charles A. LeGuin

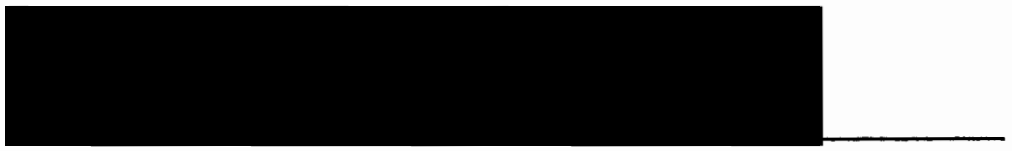

Franklin C. West

APPROVED:

Michael F. Reardon, Head, Department of History

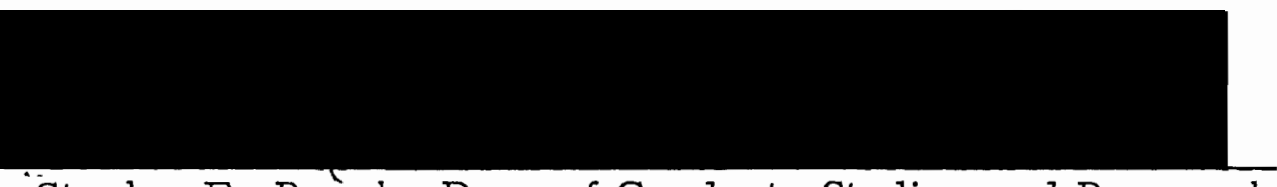

Stanley E. Raùch, Dean of Graduate Studies and Research 


\section{PREFACE}

The most explosive phenomenon of modern contemporary history has been the friction between the aspirations of "national minorities" and the ambitions of "ruling majorities." Strictly speaking, the problem is not new. It is as old as recorded history. Its intensity in recent times has been greatly stimulated by the demands of every ethnic group for an independent political existence; by the use of fair and foul means by these groups to attain that goal; by rivalries among great and small powers that often stimulate false hopes and national aspirations; and by the successful emergence of many new states.

This thesis explores briefly two experimental cases, Czechoslovakia and Poland, where between 1919 and 1938, efforts were made to solve the "minority problem." This thesis consists of five basic parts: Chapter I, an introduction that defines or describes such concepts as nationalism, nation, state, and minority; Chapter II that succinctly presents backgrounds and problems of minorities in Czechoslovakia (Germans, Magyars, Ruthenians, and Jews), and Poland (Germans, Jews, and Ukrainians);

Chapter III that analyzes the provisions of the Minority Treaties. 
prepared by the principal Allied Powers at the end of World War I to protect minority rights within Czechoslovakia and Poland;

Chapter IV that examines the implementation and results of the planned protection of minority rights in Czechoslovakia and Poland between 1919 and 1938; and Appendices that illuminate the minority problem in the two states.

The conclusion of the thesis deals with five characteristics of human behavior and human relations that surfaced in Czechoslovakia and Poland between 1919 and 1938. The perception of nationality was the first revealed characteristic. The second was the need to recognize the importance of the acceptance factor in all assimilation objectives. The great difference, in the minds of the minorities, between equality and tolerance was a third characteristic. The fourth was the realization that time, by itself, does not solve the minority problem. The fifth and final revealed characteristic was the absolute need for humanitarianism at both leadership and local levels. By connecting these five characteristics with the contemporary scene, the thesis contributes to greater interest in, and greater knowledge of, the continuing problem of the national minority.

I first became aware of the severe minority problems faced by Czechoslovakia and Poland during a course in 20th Century Eastern Europe at Portland State University. Continuing course 
discussions with Dr. Basil Dmytryshyn suggested a close connection between the minority crisis faced by those new states and the growing problems of today. I am indebted to Dr. Dmytryshyn for sharing with me his substantial knowledge of the people and politics of the subject countries, and to the members of the thesis committee for their many suggestions on matters of construction and content. The problem of the national minority can be only lightly illuminated by this thesis; further illumination must await further scholarship. 
TABLE OF CONTENTS

PAGE

PREFACE ...........................

IIST OF MAPS ..................... . viii

CHAPTER

I INTRODUCTION ............... 1

II THE MINORITIES - BACKGROUNDS AND

PROBLEMS ............. 9

Minorities of Czechoslovakia ..... 17

Germans in Czechoslovakia

Magyars in Czechoslovakia

Ruthenians in Czechoslovakia

Jews in Czechoslovakia

Minorities of Poland .........

Germans in Poland

Jews in Poland

Ukrainians in Poland

III THE MINORITY TREATIES . . . . . .

Conference Organization and Principals .

The Developing Minority Concern. . .

An Examination of the Treaties . . . 58

Treaty Opposition and Defense .... 62 
vii

CHAPTER

PAGE

IV MINORITY RIGHTS: ACTIONS AND

RESULTS ............... 73

The Czechoslovak Minorities: 1919-1938. 73

The Czechoslovak Germans

The Czechoslovak Magyars

The Czechoslovak Ruthenians

The Czechoslovak Jews

The Polish Minorities: 1919-1938...

92

The Polish Germans

The Polish Jews

The Polish Ukrainians

$\mathrm{V}$

CONCLUSIONS ........... 105

BIBLIOGRAPHY ............... 114

APPENDIX $\ldots \ldots \ldots 120$ 


\section{LIST OF MAPS}

\section{PAGE}

No. 1. Map of the Partitions of Poland ....... 15

No. 2. Map of Czechoslovakia: 1918-1938 ..... 24

No. 3. Map of Poland: 1921-1938 ........ 30 


\section{CHAPTER I}

\section{INTRODUCTION}

From Israel to Yugoslavia, from Quebec to Northern Ireland, from Africa to Asia, from the Americas to the Soviet Union, one hears the cry of the minorities. It is a call for a bomeland and for recognition. It is a plea for opportunity and for correcting past wrongs. It is an entreaty that seeks preservation of a culture, language, religion, and ethnic identity. It is a very complex and emotional problem that is as old as recorded history and as current as today's newspaper.

The cry has its source in nationalism, a force that is both very strong and very vague. In the words of C. J.H. Hayes, an eminent student of the phenomenon, "Nationalism, as we know it, is a modern development. It has had its origin and rise in Europe, and through European influence and example it has been implanted in America and all other areas of western civilization. " ${ }^{1}$ An early

${ }^{1}$ Support for nationalism as such a force is found in the introductory chapters of the following works, all by recognized authorities on nationalism. See C.J.H. Hayes, Nationalism: A Religion, (New York: The Macmillan Company, 1960); Boyd C. Shafer, Faces of Nationalism, (New York: Harcourt, Brace, Jovanovich, Inc., 1972); Hans Kohn, Nationalism: Its Meaning_and 
recognition of nationalism came from Johann Gottfried von Herder (1744-1803), a German churchman, poet, and philosopher who, in the late 18 th century, developed the theory of the nation as a "cultural community based on a common language." 2 The 19 th century saw Herder's cultural nationalism spreading over all of Europe, ${ }^{3}$ growing in the climate of liberalism that followed the French Revolution and the Napoleonic era.

The growth of cultural nationalism was particularly strong in Eastern Europe where the many minorities were politically divided among foreign rulers. Centering on possession of a language, a tradition, or a religion, cultural nationalism benefited from several new factors. One of those was the qualitative rise in education. Another was the steady rise of the middle classes and the urbanization of the general populace that followed. Still another was the development of political parties (that gave a voice to some groups), and the press that spread that voice to an increasingly literate population.

History, (New York: Van Nostrand Reinhold Co., 1965); Alfred Cobban, National Self-Determination, (Chicago: Univ. of Chicago Press, 1951). Also see International Encyclopedia of Social Sciences, Crowell Collier and Macmillan, Inc., Vol. 11, pp. 63-69. For Hayes quotation see Hayes, op. cit., p. 1 .

$$
\begin{aligned}
& { }^{2} \text { Cobban, op. cit., p. } 56 . \\
& { }^{3} \text { Hayes, op.cit., p. } 66 .
\end{aligned}
$$


Cultural nationalism in Eastern Europe developed gradually into political nationalism - that is, a conscious search for a state within which to preserve and develop the culture. This political nationalism was greatly encouraged by the emergence of such new unified nations as Italy, Germany, and Romania - all of whom were born in the last half of the 19th century with the help of blood and iron. One new nation, Norway, was of particular importance in that it was born in 1905 of pure negotiation, giving nationalism an example of a peaceful, non-revolutionary path to follow.

The growth of political nationalism, however, was impeded in Eastern Europe by the autocratic regimes of the four ruling empires - German, Austro-Hungarian, Ottoman, and Russian. This block was removed with the dissolution of all four empires during the course of World War I, thus creating the opportunity for new states. ${ }^{4}$ The growth of cultural nationalism through education, urbanization, and communication created the cohesiveness necessary for group action. The democratic development of France, Britain, and the United States, based on majority rule and the consent of the governed, set the example for the minorities to follow. At the close of World War I, nationalism in Eastern

${ }^{4}$ By 1918, the Russian and Ottoman empires had collapsed, while the defeat of Germany and Austria-Hungary was imminent. 
Europe was poised for new and rapid growth.

A discussion of "nationalism" and "nation" requires a description of those much used words, ${ }^{5}$ while the word "minority" requires a specific definition. Scholars of nationalism such as Hayes, Shafer, Kohn, and Cobban, all agree on the difficulty of defining nationalism. ${ }^{6}$ They also agree that nationalism, among its many characteristics, is very personal, that it is acquired and retained by perception, and that it is subject to change. With these authorities as the guide, and for purposes of this thesis, the following simplified description of nationalism is offered. Nationalism is a state of mind that exhibits a primary loyalty to, or affection for, a place and a group where one identifies with a common culture and a common language. The place is usually an historic homeland and the group is usually those people who share the same loyalty or affection.

As in the case of nationalism, scholars are also cautious about defining a "nation." While a common concept considers a nation synonomous with a state, the concept that is used in this

${ }^{5}$ Definitions of nationalism and nation are beyond the range of this thesis -- a description is believed to be more appropriate.

${ }^{6}$ As an example of the definition problem, Hayes takes an entire chapter to define nationalism (Hayes, op. cit., pp. 1-10) while Shafer avoids any strict definition but lists ten basic attributes of nationalism (Shafer, op. cit., pp. 17-20). 
the sis separates nation and state. For the puroses of this thesis, the word "nation" describes a "group (of some size) of people united usually, by residence in a common land, by a common heritage and culture, by common interests in the present and common hopes to live together in the future, and by a common desire to have and maintain their own state. $" 7$ To illustrate this concept, the Ukrainian and French-Canadian nations exist today within the USSR and Canada.

The word "minority," as used in this thesis, needs an explanation as well as a definition. In the United States, the PolishAmerican might be better referred to as an American-Pole in that his primary identification is with his American citizenship even though he maintains a concern for his Polish heritage and culture. This is not generally true in Eastern Europe and specifically, for purposes of this thesis, in Czechoslovakia and Poland. In Eastern Europe, including the subject countries, the minorities are large groups of people that have a long history of occupying their present lands. They have their own language, their own culture, and, moreover, have never willingly left their ancestral homes. They consider themselves Magyars (Hungarians), or Germans, or Slovaks, or Ruthenians, whose fate placed them under the political control of

${ }^{7}$ Shafer, op. cit., p. 15. Emphasis added. 
some state that differs from their own nation. With this in mind, for purposes of this thesis, the definition of a minority will be: a population group that has a primary identification with its own perceived nationality, which differs from that of its state of residence. Thus a Magyar in Czechoslovakia is part of a defined minority while his brother in Hungary is not.

The end of World War I brought the victorious Allied and Principal Powers together at the Paris Peace Conference.

Woodrow Wilson's Fourteen Point plan for peace, proclaimed in January, 1918, set the guidelines for the Conference. ${ }^{8}$ Selfdetermination, as described in Point $\mathrm{V}$ of the Wilson plan, was the leading principle. 9 Across Eastern Europe this principle of self-determination excited the many minorities and brought them to Paris to plead their cases for independence. It soon became apparent to the conferees that the re-alignment of the states of Eastern Europe could not follow strict nationality lines. Almost

${ }^{8}$ See Appendix D for a complete text of Wilson's Fourteen Points. The Wilson speech was delivered on January 8, 1918, but prior events had set self-determination in motion. In the fall of 1916, a British Foreign Office Memorandum stated the "principal of nationality should be one of the governing factors in the consideration of territcrial arrangements after the war." In March, 1917, the Russian Provisional Government announced support for "the right of the nations to decide their own destinies." See Cobban, op. cit., pp. 12-13.

${ }^{9}$ Cobban, op. cit., p. 116. 
every decision involving state boundaries necessarily created, or left, minority groups within the new state. As the party responsible for the final state decisions, the Conference had a very real concern for the welfare of the new, or remaining, minorities. That concern took the form of special Minority Treaties with each of the new states of Czechoslovakia, Poland, Romania, and Yugoslavia, as well as the form of special provisions in the peace treaties with Austria, Hungary, and Bulgaria.

Two of the new states, Czechoslovakia and Poland, presented special problems. A combination of geographic and economic considerations, plus a complete intermingling of ethnic populations within many villages and cities, led to unanticipated and very large minorities. Overnight the old rulers (Germans and Magyars) became ruled minorities - while some of the old minorities (Czechs, Slovaks, and Poles) now became rulers. ${ }^{10}$ Once the boundaries, and thus the minorities, were in place and the treaties in force, the years between 1919 and $1938^{11}$ brought only increasing minority problems

${ }^{10}$ The use of the terms "rulers" and "ruled" needs an explanation. Henceforth, the thesis will refer to the population group holding political control of the state as the "rulers" (the Poles in Poland) and to the minorities within the new state as the "ruled." Where the reference is to a ruling class or group of leaders, the thesis will so state.

11 By 1938 the effects of Hitler's actions were distorting all minority situations. 
instead of the desired national unity.

Buried somewhere in the ambience of the Paris Peace

Conference, in the Minority Treaties that followed, and in the subsequent interchange between the rulers and the ruled of Czechoslovakia and Poland, may be a better understanding of the basic interests of the ruling majority and the ruled minority. 


\section{CHAPTER II}

\section{THE MINORITIES - BACKGROUNDS AND PROBLEMS}

Who were the minorities of Czechoslovakia and Poland during the years from 1919 to 1938 ? What was the historical background of each group? What special problems did each minority present to the ruling majority? Before addressing these questions, a brief background review of each country is necessary, for in that background are some of the latent factors that had an effect on the Paris Peace Conference as well as on the post-war treatment of the minorities.

Frantisek Palacky (1798-1876), author of the History of

Bohemia and considered one of Czechoslovakia's great men, argued that "Nature knows no ruling and no serving nations." Nature has had much to do with the Czechoslovak state as one can see from a look at the geography of Europe. Composed of two primary sectors (Bohemia-Moravia and Slovakia) and one

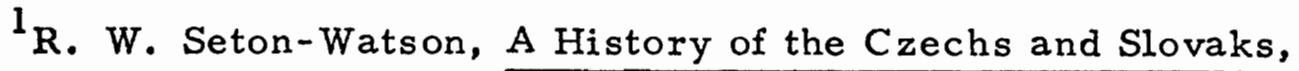
(Hamden: Archon Books, 1965), p. 186. 
smaller sector (Ruthenia), ${ }^{2}$ Czechoslovakia of 1919 had generally distinct frontiers, geographically speaking. The new state was bordered by the Bohemian forest on the southwest, by the Ore and Sudeten mountains on the west and northwest, and by the Carpathian mountains on the north and northeast. In the south were the Carpathian foothills that tapered down to the Danube and the Hungarian plains, marking Slovakia as an area quite distinct from Hungary.

Each of the three sectors of Czechoslovakia had its own characteristics. The historic home of the Czechs was the ancient area of Bohemia-Moravia, separated from Slovakia as early as 900 A.D. when the Magyars moved north out of Hungary into Slovakia but not westward to Bohemia. With river and land passages to the north, and the Magyar control to the east, the Czechs were heavily influenced by western societies in general and by the Germans in particular. ${ }^{3}$ The Slovaks, on the other hand, have historically been forced to look south to Hungary. The mountains that were their home, and the Magyar control that blocked their

2 William V. Wallace, Czechoslovakia, (Boulder: Westview Press, 1976), pp. 135-36. The technically correct name for this area is "Sub-Carpathian Ruthenia" or "Podkarpacká Rus." It bordered on Poland, Romania, and Hungary -- he reafter referred to as "Ruthenia."

${ }^{3}$ R. W. Seton-Watson, op. cit., p. 251. 
opportunities, led the Slovaks into an isolated and backward existence as compared with the Czechs or Magyars. The third sector, Ruthenia, was at the extreme eastern end of the new state. With the Carpathian mountains. separating them from their kin in Galicia, the Ruthenians lived an isolated mountain life, dominated and economically controlled by the Magyar rulers. 4

The Czechs were the dominant group in the new state and they brought to the state a number of great advantages. In addition to a sound economic base in Bohemia, the Czechs had also developed one of the best balanced societies in Europe. With no traditional ruling or aristocratic class, the bourgeoise, workers, and peasants all participated in society to some degree. That same society produced a number of very competent leaders, men who were recognized for basic ability as well as leadership, and who were led by Thomas G. Masaryk (1850-1937) President of the new state until 1935. ${ }^{5}$ In spite of these advantages, the new state was still a major gamble when one bears in mind the long standing and very prominent German bloc in the Czech lands (see Appendix C), the basic differences between Czechs and Slovaks, and the substantial

4. Ibid., p. 324. Ruthenia's common borders with Poland, Hungary, and Romania gave it a strategic importance. Since 1946, Ruthenia has been a part of the USSR.

${ }^{5}$ Hugh Seton-Watson, Eastern Europe Between the Wars: 1918-1941, 3rd ed., (Hamden: Archon Books, 1962), p. i84. 
Magyar population and control of Slovakia and Ruthenia. It should also be noted that the se lands were part of the Austro-Hungarian empire as of 1914. While under the rule of the Austrian Germans, the Czechs continued a prominent role in the Czech historic lands, while the Slovaks and Ruthenians under Magyar rule were described as "dominated and deprived." ${ }^{6}$

Poland in 1919 presented an entirely different situation from that of Czechoslovakia. The new state was a re-birth of a very old country. Raymond Leslie Buell, in his book, Poland: The Key to Europe, ${ }^{7}$ describes Poland of the 16 th and 17 th century as the "freest state in Europe... in which the greatest degree of constitutional, civil, and intellectual liberty prevailed." He goes on to term Poland the "melting pot of Europe," with "almost complete toleration and an asylum to those fleeing from persecution in all Western lands." He also maintains that the complications of the later minority problems are partially rooted in the influx of Germans, Jews, Magyars, Russians, and others who sought asylum in Poland. However, by the 18th century, the ruling classes of Poland had become so oriented to self-interest that "independence

${ }^{6}$ R. W. Seton-Watson, op. cit., see Chapters XIII and XIV for details of $\mathrm{Czech}$ and Slovak political and cultural life under their Austrian-Hungarian rulers.

7Raymond Leslie Buell, Poland: The Key to Europe, (New York: Alfred A. Knopf, 1939), pp. 28-29. 
for all" had become "oppression for all" under an almost anarchial condition. In this same era, Europe saw the rise of Austria, Prussia and Russia, with Poland squarely in the middle. The expansive pressures of these three powers, together with the leadership vacuum in Poland, led to a series of three partitions between 1772 and 1795, whereby Poland was divided among the three powers, and ceased to exist as a state in $1795 .^{8}$

The Polish state died, but it is most important to remember that the Polish nationality did not. Throughout the more than one hundred years of life in partitioned Poland, the Polish people maintained their nationality. The partitions divided the country into three areas: western Poland went to Prussia, southern Poland became a part of Austria, and the center and eastern areas were incorporated into Russia. In 1807, Napoleon created the Grand Duchy of Warsaw, and in 1815, the Congress of Vienna created out of the Duchy a political unit known as the Congress Kingdom, centered in Warsaw and with Polish administration, but under Russian rule.

From 1795 to 1914 , the position of the Poles under each of

8 In addition to the Wandycz test cited in Note 38 , the story of these partitions may be also found in R. H. Lord's, The Second Partition of Poland, Cambridge: Harvard Univ. Press, (1915), and Herbert H. Kaplan's, The First Parition of Poland, (New York: Columbia Univ. Press, 1962). 
the powers (Russia, Austria, Prussia-Germany) varied considerably. Under Russia, while there was much discontent, there was Russian recognition of the permanency of the Polish nationality and there was always an element of Slavic relationship. ${ }^{9}$ In the Austrian sector, the problems of the Habsburg rulers in their own heartlands after 1867 led to an autonomous rule for southern Poland (Galicia). While the Poles of Galicia had opportunities to grant local control, their control efforts were always aimed at "polonizing" Galicia in spite of the presence of two very large minority groups - Ukrainians, who made up almost half the population; and Jews, who made up about $10 \%$ of the population and were very prominent in local trade. 10 The situation in the Prussian (German) sector of Poland was quite different and bears on the later developments regarding the German minority. ${ }^{11}$ Briefly, the German goal in Poland was to make the Polish lands a permanent part of Germany by colonizing (an active policy under Bismarck) and by converting the Poles into

${ }^{9}$ Buell, op. cit., pp. 57-59. This does not refer to friendship but more to a common denominator that did not exist in the partitioned lands ruled by Prussia and Austria. While the Russians envisaged a vague Pan-Slav empire, the Poles constantly resisted Russian rule, rebelling in 1830 and again in 1863.

10 Ibid., pp. 62-63. Also see O. Halecki, A History of Poland, (New York: Roy, 1943), pp. 259-260).

${ }^{11}$ In 1871, Prussia became part of the German. Empire. All continuing references will be "German" instead of "Prussian." 


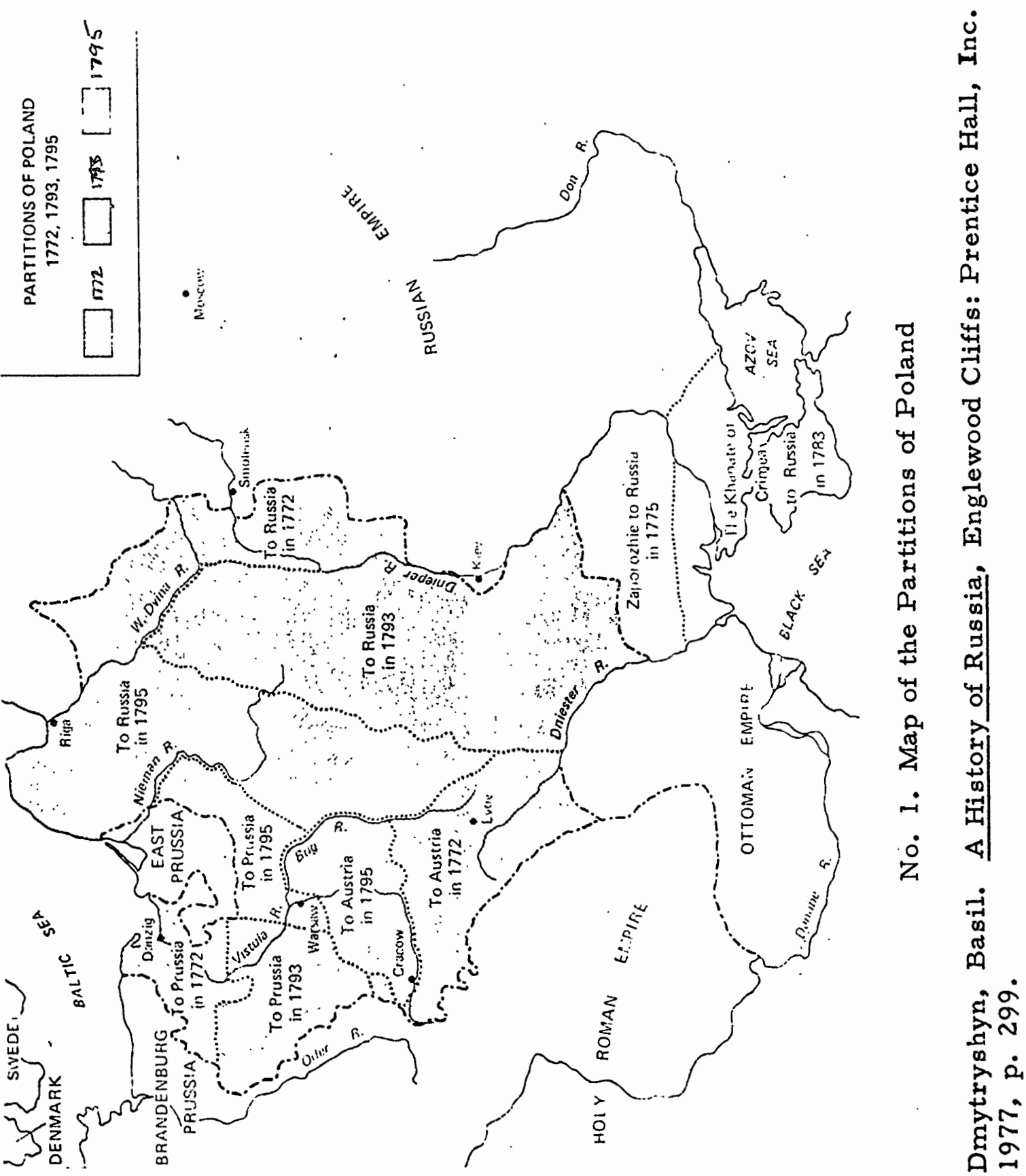


Polish-Germans. ${ }^{12}$ The effect of this policy was the reverse of its objective. The Poles were not converted. On the contrary, in addition to some armed resistance, the Poles adopted a policy they termed "organic work." This policy turned away from insurrection and concentrated on the development of Polish economic and social interests within legal limits. The late Professor Oscar Halecki, honorary editor of the Slavonic Review and noted authority on Poland, states the policy was pursued in all three partitioned areas with great benefit to the Polish people.

The Polish people at the start of World War I were a nation without a state. Yet the historic lands of Poland, the return of which the Poles were constantly demanding, did not constitute a state of one nationality. These historic lands had been the home of millions of non-Poles for generations. The actions of the Polish ruling class in the years before and during the partitions showed little evidence of Polish acceptance of any principle of federation or understanding of minority rights and aspirations.

With this brief but basic background of the new Czechoslovakia

12 Buell, op. cit., pp. 59-60. Halecki, op. cit., p. 257, puts it more strongly, alleging it was a Bismarck policy to "exterminate the Poles."

13 Halecki, op. cit., pp. 258-62. These pages detail the application of the policy in each of the partitioned areas as well as the resulting preservation of Polish life. 
and the re-born Poland in mind, the backgrounds and problems of the principal minorities of those new states can now be reviewed (see Appendix A, B, C, for a racial and religious breakdown of the populations of Czechoslovakia and Poland in 1921 and 1931). ${ }^{14}$ As the census shows, over $34 \%$ of the population of Czechoslovakia was non-Czech or non-Slovak. In the new Poland, a comparable figure for non-Poles was almost $31 \%$. These millions of "non-people" were the minorities.

\section{MINORITIES OF CZECHOSLOVAKIA}

In addition to the large minorities within the new state, the Slovak population presented the Czechs with a special situation. Though a part of the new state by name and law, the Slovaks were distinctly different from the Czechs in language and in almost all modes of life. ${ }^{15}$ They numbered about 2, 000,000 as compared with about $6,800,000$ Czechs. While never possessing its own state, the Slovak nation had a long history of national activity in for 1918 .

${ }^{14}$ The 1921 figures are accepted as essentially accurate

${ }^{15}$ R. W. Seton-Watson, op. cit., Chapter XIV. The commentary on Slovakia is a summary of the very complete review of Slovakia under Hungarian rule as found in this chapter. 
spite of constant Magyar pressure. ${ }^{16}$ In the 17 th century, while Hungary was under. Turkish rule, Magyar nobles turned Slovakia into a center of Habsburg loyalty and resistance to the Turks. 17 Following the formation of the Austro-Hungarian Dual Monarchy in 1867, the Magyars launched a strong Magyarization program across all their lands. In Slovakia the Magyarization effect was to severely retard Slovak economic, educational, and cultural development. ${ }^{18}$ Even though the Slovaks were dominated and deprived, the Slovak nationality survived in the homes, fields, and villages and surfaced from time to time in the form of Pan-Slavic theories and in the presence of Slovak leaders such as Ludevit S̆tur (1815-1856) and Joseph Hurban (1827-1888). ${ }^{19}$ As one ponders the nature of each minority, this Slovak situation tells something of the inherent strength of the force called nationalism. While the Czechs and Slovaks shared a common Slavic heritage, their development was

${ }^{16}$ Ibid., p. 253. In addition to Magyar rulers, German colonization dated back to the 13 th century when German settlers established their own towns, with special German codes of privileges, such as the "Magdeburg Law."

17 Ibid., p. 255.

18 In 1868, the Hungarian "Law of Equal Rights of Nationalities" was enacted, but historians such as R. W. SetonWatson and C. A. Macartney agree that the law was only a facade, behind which the policy of total Magyar rule was locally carried out.

${ }^{19}$ R. W. Seton-Watson, op. cit., pp. 259-264. 
substantially different. The successful uniting of these two nations under one state was a tribute to the enlightened leadership of men such as Masaryk and the Slovak leader, Anton Stefanik (1880 $1919) .^{20}$

Apart from the Slovaks, who became part of the ruling majority, there were four principal minorities in the new state: Germans, Magyars, Ruthenians, and Jews. 21 The review of these groups will follow the form of answers to three questions: How did they get there? What was their economic and cultural situation in 1918? What special problems did they present to the new nation?

\section{Germans in Czechoslovakia}

There are historical records of both German and $\mathrm{Czech}$ occupation and rule of the lands of Bohemia that are so intertwined as to lead Robert Seton-Watson, eminent scholar and authority on Eastern Europe, to assert, "It is very difficult to decide what are the relative proportions of Celtic and Teutonic blood in the population

20 Ibid., pp. 244-46, and pp. 311-12. While much has been written about the leadership of Masaryk, this text includes an excellent summary of Masaryk by one who was a close fiend and ally. Stefanik was a leader of the new state movement, now "enshrined in national legend as Slovakia's greatest hero."

${ }^{21}$ There were also 75,000 Poles -- largely in the Teschen area of Silesia where there was a major borcier dispute with Poland, See Appendix B and C. 
of today. $" 22$ Germans came to Bohemia very early and stayed very late. German colonizing of Bohemian lands, going back to the 12 th and 13 th centuries, brought such heavy German influence that the Germans have been referred to as "forming something not far removed from a state within a state. ${ }^{23}$ In 1918, the Germans were recognized by the Czech leadership as well as the Paris conferees as a major problem to the new state, so much so that the Czech leader, Thomas Masaryk, in advocating the principle of nationality stated that it was this very principle that required this large German minority to remain within the new state, his reasoning based on the very heavy mixture of Germans and Czechs in "almost all the cities of Bohemia." 24 The compromise with ethnic unity in this German situation was dictated by economic considerations on both sides. Many German industrialists in Bohemia preferred to remain with their Czech markets while Czech industry recognized the viable economic life of the new

22 R. W. Seton-Watson, op. cit., p. 11. Seton-Watson wrote this book in 1943.

23Ibid., p. 17, For a history of Bohemia, see R. J. Kerner, Bohemia in the Eighteenth Century, (Orno: Academic International, 1969).

24 Robert Seton-Watson, Masaryk in England, (Cambridge: Cambridge Univ. Press, 1943), p. 128. 
state depended on retention of the German-dominated industry. 25 While the German minority presented many problems in areas of culture, education, and native languages, this economic consideration was over-riding. The Paris conferees recognized the dangers but voted unaminously for the Czech historic frontiers rather than for some gerry-mandered border aimed at reduction of the German minority. ${ }^{26}$ Vaclav Beneš, in his paper on Czechoslovak Democracy and Its Problems ${ }^{27}$ compares the German and Czech cultural position. He states that while the Germans had a somewhat higher living standard, and were more conscious of rank and class than the Czechs, the differences were not very great. The special problems presented by Germans were their very size, prominence, and long resident-history. Those problems were complicated by the presence of both the Weimar Republic and German Austria, giving the German minority two neighboring states to look to for protection, sympathy, or support.

${ }^{25} \mathrm{~J}$. W. Bruegel, "The Germans in Pre-War Czechoslovakia," in History of the Czechoslovak Republic: 1918-1948, ed., Victor S. Mamatey and Radmii Luza, (Princeton: Princeton Univ. Press, 1973), p. 171. Hereafter cited as HCR.

${ }^{26}$ Ibid., p. 171 .

$27_{\text {HCR, op. cit. }}$ pp. $46-47$. 
Magyars in Czechoslovakia

There were about 750, 000 Magyars in Slovakia and Ruthenia in 1918, and they had been there as rulers for a very long time. As of 1918, Magyars were almost $25 \%$ of the total population of Slovakia and about $20 \%$ of the population of Ruthenia. The Magyars held a dominant position in trade and commerce and, according to Vaclav Beneš, held and worked the more fertile plains of southern Slovakia. 28 This left Slovakia and Ruthenia with a very difficult problem as the ruled became the rulers. The Slovaks and Ruthenians, who had suffered from a very backward economic and educational system under the Magyar rule, found themselves without the tools of leadership. Seton-Watson points out that the number of "educated and nationally conscious Slovaks in 1918 did not exceed 750 to 1,000," while in Eastern Slovakia "hardly a single candidate for office was available." 29 A further complication was the widespread refusal of Magyar civil servants, teachers, and professionals to serve the new state. This made it necessary to staff the governmental offices and schools of Slovakia and Ruthenia with Czech personnel, a decision that created a further irritant.

The special problem presented by the Magyar minority was

28 Ibid., p. 47.

${ }^{29}$ R. W. Seton-Watson, op. cit., p. 283. 
the conversion of the rulers into the ruled - a transition made even more difficult by the continuing active support given the Magyar minority by Hungary. Everyone welcomes the chance to move up to rule but few, if any, will willingly step down to be ruled.

Ruthenians in Czechoslovakia

Ruthenians and Ukrainians are historically and ethnically the same people. The Ruthenians became separated from their Ukrainian kin in eastern Galicia, Bukovina, and the Russian Ukraine many centuries ago. They settled in the Carpathian mountains just east of Slovakia where they lived an isolated life under Magyar rule. Within Ruthenia they were a majority $(62 \%)$ - Magyars and Jews comprising $17 \%$ and $13 \%$, and Czechs only $3 \%$ of the population (see Appendix C). The Magyarization policies of the rulers resulted in Magyar dominance of education as well as almost total Magyar and Jewish control of trade and industry. Seton-Watson tells of the very deprived condition of the Ruthenians in education, economics, and political representation, indicating the Ruthenians were "seemingly ripe for final as similation. ${ }^{30}$

But the Ruthenian nationality lived on. It was kept alive in the isolated lives of the mountain villages and homes, by periodic

30 Ibid., p. 324. Ruthenian activity from 1919 to 1938 indicates that Seton-Watson misjudged the durability of Ruthenian nationalism. 


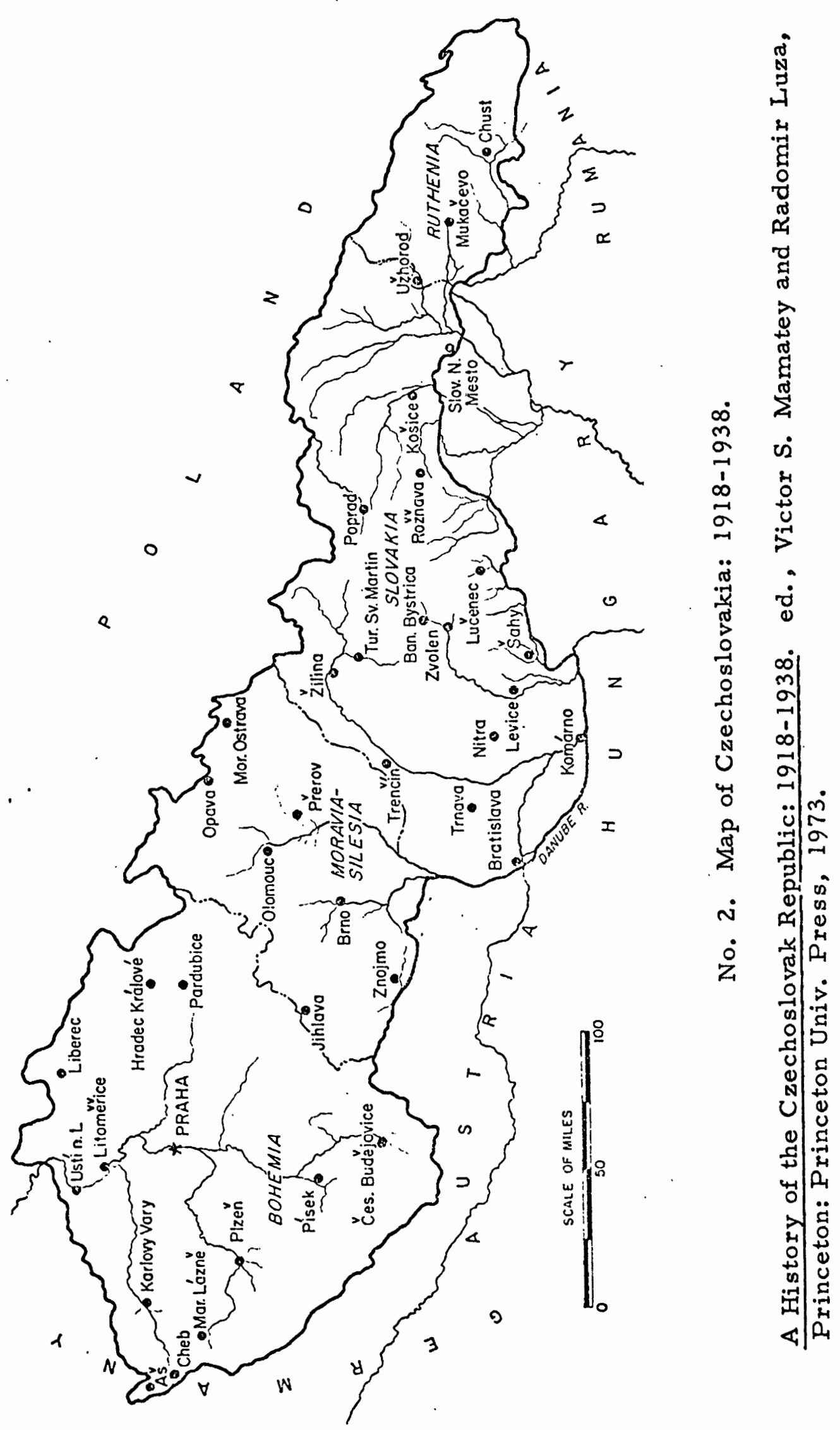


cultural revivals led by local leaders such as Adolf Dobriansky (1817-1901), and by the many emigrants residing in the United States and Canada. When the voices were heard for the new Czech-Slovak state, Ruthenian representation was present from the beginning. Ruthenian National Councils appeared within Ruthenia and Ruthenian emigrants were part of a Congress convened in the United States in July, 1918, to discuss Czechoslovakian independence.

This small and remote province contained non-Czech minorities that made up $96 \%$ of the provincial population. In joining with the new state, Ruthenian leaders sought an autonomous arrangement. It was this autonomy requirement that presented the major problem to the new state - how to grant autonomy to this remote province in the absence of any cadre of Ruthenian administrators?

\section{Jews in Czechoslovakia}

The Jews in the new state were a small group, concentrated in Slovakia and Ruthenia but also present in Bohemia-Moravia. Appendix B and C shows a religious population of 360,000 and a "racial" population of 180,000. The Jews of Slovakia and Ruthenia came largely from Galicia and Russia and almost immediately identified with the Magyars, becoming not only Magyars, but the

31 Ibid., p. 324. The Congress was held in Homestead, Pennsylvania, and included a broad area of Eastern European concerns. 
most vocal Magyars. ${ }^{32}$ Economically, these Jews became the small merchants, the middlemen, the money lenders, and gradually became prominent in all trade and industry. In the Czech lands of Bohemia-Moravia, the Jews were mingled with the German population, and involved in both industry and finance.

In the village-oriented societies of Slovakia and Ruthenia, there was substantial anti-Semitism. In the words of Stefanik, the Slovak leader, "The Jew is considered the exponent of the Magyars and they are feared everywhere. ${ }^{33}$ Seton-Watson supports the Stefanik opinion by saying, "It cannot be denied that the Jews exploited the Slovak masses and played the game of their Magyar oppressors. " 34

The problem of anti-Semitism was of major concern to the Czechs as they assumed the leadership of the new state. As the Germans and Magyars were reduced to secondary roles in the new administration, it was necessary for the Czechs to make this

${ }^{32}$ The Jews are an exception to the description of an east European minority. Some Jews identified with their state of residence, but most of them did not. See Appendix $A$ and $B$ for the number of Jews claiming a Jewish nationality.

${ }^{33}$ Harriet Wanklyn, Czechoslovakia, (London: George Phillip and Son, Ltd., 1954), pp. 403-404.

${ }^{34}$ R. W. Seton-Watson, op. cit., p. 272. In discussing Slovak anti-Semitism, Seton-Watson sees Jewish actions as a major cause. 
change without drawing anti-Semitic accusations from the many Jews that were a part of the German and Magyar structure. ${ }^{35}$ At the same time, the Czechs had a great need for the talents of the Jews in the administration and development of Slovakia and Ruthenia, the provinces where anti-Semitism was most prevalent prior to 1918.

\section{MINORITIES OF POLAND}

The 1921 census showed $31 \%$ of the population to be nonPolish. While the re were more than $1,000,000$ White Russians in the eastern provinces, the minorities that were of primary concern to the Poles and to historians were the Germans, Jews, and Ukrainians. 36

Germans in Poland

"Drang nach Osten" (movement or pressure to the East) has been a German slogan or mission for a long time. ${ }^{37}$ An aggressive

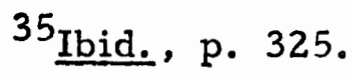

${ }^{36}$ Although a defined minority, the concentration of historians on the Germans, Jews and Ukrainians as the principal minorities justifies the omission of the White Russians from this thesis.

37

Henry Cord Meyer, Mitteleuropa in German Thought and Action: 1815-1945, (The Hague: Martinus Nijhoff, 1955). This entire text deals with this subject in detail. 
people, the Germans long ago realized that any westward expansion was blocked by the French and could be achieved only by conquest. To the east, however, lay great open areas, thinly populated and in need of both a skilled labor force and creative management. The rulers of the eastern lands recognized this need to develop the lands and so history records many instances where German immigration was encouraged - by Russians, Magyars, Czechs, and Poles. German emigration was likewise encouraged by Germans for it furthered several German objectives, among them being population relief, future German markets, and the development of a German position in the local society that would assist future German expansion.

This latter objective, a German position in the local society was also pursued through a policy of colonizing. In 1886, in support of the nationalistic "Hakatism" movement, Bismarck promoted a major colonizing program throughout the eastern provinces of Posnania and Pomorze. 38 The Polish reaction to Hakatism and to the colonizing program brought the Poles ever closer together, making

38 Piotr S. Wandycz, The Lands of Partitional Poland: 17951918, (Seattle: Univ, of Washington Press, 1974), p. 225. This German colonizing of Poland, the later Polish colonizing of Galicia, and the Czech colonizing of Slovak areas all bear a striking resemblance to the current Israeli colonizing of the West Bank and the Sinai; particularly so since many of the Israelis, including Begin, came from Poland. See also Halecki, op. cit., p. 258. "Hakatism, "after the initials of its leaders, became synonomous with German nationalism. 
the Poles of Germany "the most nationalistic faction of the Polish nation, and the most bitter enemies of Germany. " 39

The industrial influence of the Germans in Poland was substantial and widespread. In Upper Silesia, the Germans were very prominent at both management and worker levels. In the textile center of Lodz, within the Russian partition, the Germans were about $10 \%$ of the population and held the majority of the engineering, technical, and executive positions. 40

Economically and culturally, the German minority in restored Poland was better balanced than either the Poles or the other minorities. The Germans ranged from industrial executives to workers, from large estate owners to small farmers, from urban dwellers to the villagers. Whether due to land selection or land management, German farms had a "much higher yield per hectare" 41 than the average Polish farm, and Germans held a large share of the wealth of the western provinces.

The special problem presented by this German minority was at least threefold. First, was the substantial economic position of the Germans and how to meld their industrial and agricultural base

${ }^{39}$ Buell, op. cit. p. 60.

40 Ibid., pp. $246-47$.

$41_{\text {Ibid., p. } 247 .}$ 


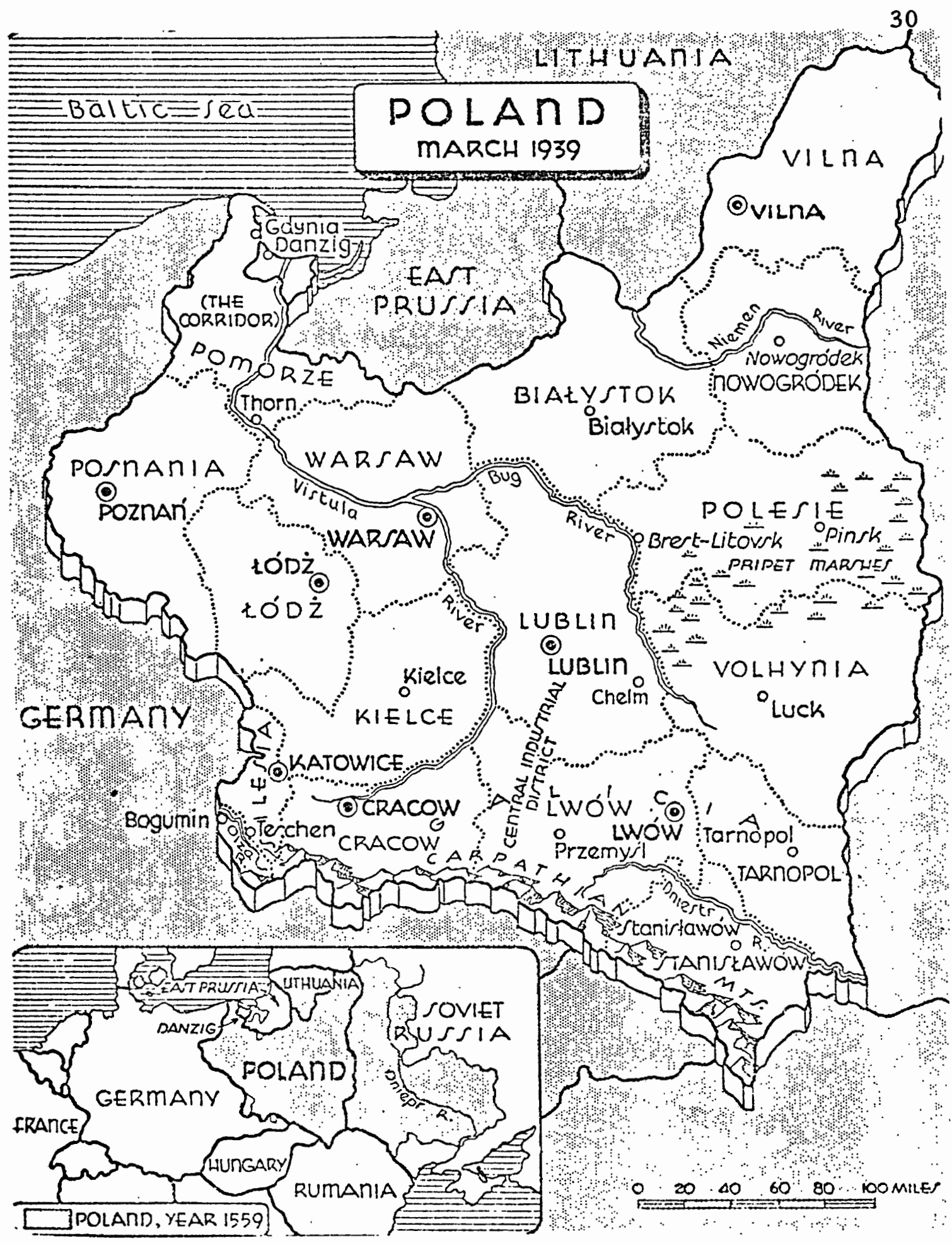

No. 3. Map of Poland: 1921-1938.

Raymond Leslie Buell. Poland: Key to Europe, 3rd ed., (New York: Alfred A. Knopf, 1939). 
with the Polish efforts. Second, was the threatening shadow of Germany, with a large Polish population in her eastern lands and smarting from the loss of the partitioned provinces. The third major problem area related to the many natures of the individual Germans. Could they live with or under the Poles? Where did their loyalties lie? Hugh Seton-Watson saw it all as a most serious problem, for which he could offer no solution and, by way of emphasis, commented on German regard for the "German race appointed by God to rule." 42 Numbering from 800,000 to $1,000,000$, less than $4 \%$ of the total population, the German influence went far beyond their numbers.

\section{Jews in Poland}

The 1921 Polish census showed about 2,100,000 Jews in Poland that claimed Jewish nationality, with about $3,100,000$ that identified with the Jewish religion (by 1931, the nationality total was up to $2,700,000) .^{43}$ The Jewish minority was about $10 \%$ of the total population and the largest group of Jews in the world outside of the

42 Hugh Seton-Watson, op. cit., p. 281. This was written in 1943. The climate of war may have had an influence on the comment.

${ }^{43}$ The census indicates that about 1,000,000 Jews claimed a Polish nationality for various personal reasons. The Jewish nationality increase in 1931 reflects the polarizing trend discussed in Chapter IV. See Hugh Seton-Watson, op. cit., p. 414. 
United States. Origins are indistinct at best, but a review is called for. Eastern European Jews have two branches - the Western or Sephardic branch came out of Spain in the late 15th century and found their way into Europe via the Ottoman empire. The Eastern or Askenazi branch has two origins. Some of the Askenazi Jews are no doubt descendants of the Diaspora (the wanderers from the Holy Land). Some may also go back to the Khazars, a Mongol tribe from the steppes of Eurasia that adopted Judaism back in the 9th century, and were known to have reached Poland in the 14th century. 44 Probably the largest number of Jews in Poland came out of western Europe, responding to two primary incentives. First, Polish rulers had a long history of encouraging Jewish and German immigration. Going back to the 13 th and 14 th century, kings such as Boleslav in 1264 and Casimir the Great in the mid-14th century welcomed such immigration and granted the se Jews special privileges and protection against clerical opposition. In those long-gone days, the Jews were needed to fill the growing requirement for merchants, tradesmen, and financiers, for the Polish population provided only nobility or agricultural labor, a situation similar to many other European states. The second migration incentive came out of the rising anti-Semitism of the west, fed by the increasing intolerance 
of the church as well as the gradual entry of the non-Jewish population into the occupations that were originally and then traditionally, Jewish. 45

As the Jews spread across the Polish lands, they developed a heavy urban residence. While numbering about $10 \%$ of total population in 1921, there were some very substantial concentrations. The city of Bialystok in Polish Lithuania was about $75 \%$ Jewish in 1919. A smaller town of Sokolka (total, 5,500) was $60 \%$ Jewish. Cracow had 30,000 Jews out of a total population of 90,000 , and the industry (textiles) of the city of Lodz was controlled by Jews and Germans. 46 This urban presence resulted from the Jews turning to the obvious economic needs (merchants, tradesmen, the professions), the difficulty of acquiring land in many areas, and a disinclination toward agriculture on the part of many Jews.

Several factors combined in Poland to create an atmosphere of anti-Semitism. Within the cauldron of a re-born nationalistic Poland could be found a large Jewish presence, a Catholic Polish tradition, and a poor, war-ravaged economy. The Jewish presence

${ }^{45}$ Arthur I. Goodhart, Poland and the Minority Races, (London: George Allen and Urwin, Ltd., 1920). Celia S. Heller, On the Edge of Destruction, (New York: Columbia Univ. Press, 1977). While there are many historical references to this Jewish movement, excellent summaries are found in the Appendix of the Goodhart diary and in the first two chapters of Heller.

${ }^{46}$ Goodhart, op. cit., pp. 43, 46, 110, 123. 
was complicated by the Jewish tradition, for the Jews lived apart. The Orthodox Jews (most of the Jews in Poland) dressed differently in their long caftans, hats, and beards. They worshipped differently with their Saturday Sabbath setting them apart in a predominantly Catholic land. They talked differently, not only with the Yiddish language but also with gestures, expressions, and mannerisms that set them apart. In the opinion of Celia Heller, Professor of Sociology, Hunter College, they maintained a "high visibility" with the probability that $80-90 \%$ of the Jews were instantly identified as Jews upon sight or sound. ${ }^{47}$ This innate separatism of the Jews recycled opinions againsi them and contributed to the anti-Semitism.

There was also a political factor. Some of the Jewish youth, in turning away from Jewish ways, had a tendency to join with the Germans and the Bolsheviks, Poland's two principal adversaries. The Goodhart diary, a personal account of the counsel to the Morganthau Mission sent to Poland in 1919 to investigate the position of the Jews, has repeated references to the Polish hatred for the Jewish Bolsheviks and the constant use of that label as the excuse for many forms of anti-Jewish violence. 48

What exactly was a Jew in Poland in 1919? A Pole? A

${ }^{47}$ Heller, op. cit., pp. 69-70.

${ }^{48}$ Goodhart, op. cit., pp. 70-103. Chapter III concentrates on the Bolsheviks in Poland. 
citizen? An alien? To appreciate the need for the questions and the difficulty in coming up with specific answers, it will be helpful to review very briefly some Jewish history of the 19th century. In 1791, the French National Assembly granted full citizenship rights to Jewish subjects. In the following century, "Jewish emancipation in most countries of Western Europe was complete. "49 With the opportunity for full citizenship, the Jewish community was faced with the problem of clarifying their religious, nationality, and citizenship status. A Reform Movement called for changes that would maintain the Jewish religion while altering Jewish dress codes and even Sabbath observances. The Reform objective was to encourage the Jew to be a Frenchman or Englishman or German, but of the Mosaic faith. Orthodox Jews rose in opposition, holding to the need for Jewish nationality, and a Conservative Movement arose between the two extremes.

Organized Jewry in Poland of 1919 remained officially Orthodox. The majority of Jews in re-born Poland held to Jewish ways and a Jewish nationality, but the re were some defections. Some of the defectors were known as "assimilators," a term applied to that segment of the Jews that took (or tried to take) the

${ }^{49}$ Isadore Epstein, Judaism, (London: Penguin Books, Ltd., 1959), pp. 290-91. Chapter 21 of this text gives details of the problems and movements that the study so briefly summarizes. 
path of assimilation. ${ }^{50}$ Specifically, this involved changes in dress, habits, diet, manners, and language - in short, be a Pole, but of the Mosaic faith. The assimilators were few in number and tended to be the wealthier and better (or broader) educated Jews. Assimilation, however, while reducing Jewish visibility, did not make the assimilators "Polish." In many public and private ways they were "exposed" as hidden Jews in a land that was predominantly Catholic. Meanwhile, the Orthodox Jews were splintering their political position with the Zionist and the Bund movements. The Zionist held strictly to a Jewish nationality and for a Jewish homeland, Israel. The Bund was the party of the Jewish Socialists. Their interests were primarily in a class struggle, not in Zionism and not in the Jewish people as a whole. 51

The special problem presented by the Jews was not primarily numbers or economic position or daily conflicts - it was just a simple hatred. Most of the Poles seemed to hate most of the Jews, and since the Jews were both numerous and often strategically

50 Note the definition of assimilation - to "absorb into the cultural tradition of a population."

${ }^{51}$ Goodhart, op. cit., pp. 192-93. For additional support for these generalizations, see Epstein, op. cit., pp. 309-316 in Zionism, and Irving Howe, World of Our Fathers, (New York: Harcourt, Brace, Jovanovich, 1976), pp. 292-94 on the Bundist movement. 
positioned in their urban pursuits, it was a very critical problem. 52

Ukrainians in Poland

The historic lands of the Ukrainian nation range from the northern shores of the Black Sea, north along the basins of the Dnieper and Dniester rivers, to the Galician provinces of Lwów, Tarnopol, and Stanislawów. The Ukrainians and Russians are both part of the eastern branch of the Slavic people, whereas the western branch includes the Poles, Czechs, and Slovaks. ${ }^{53}$ Centuries ago the Ukrainians developed their own language and distinct culture although their political history is one of division under Russian, Polish, Lithuanian, and Austrian rule. There have been brief intervals of independence, starting in the days of ancient Kiev ( 9 th and 10 th centuries) and occurring periodically up to 1917 when a People's Ukrainian Republic was proclaimed following the collapse of Imperial Russia. 54

${ }^{52}$ After a study of the Heller text, the Goodhart diary of the Morganthau Mission, and the writings of Buell, Seton-Watson, and Wandycz; the phrase, "The Poles hated the Jews" seems the only accurate way to put it.

${ }^{53}$ Buell, op. cit., p. 254.

${ }^{54}$ A very complete review of Ukrainian history may be found in Ukraine: A Concise Encyclopedia, 2 Vol., ed., Volodymyr Kubijovyc, (Toronto: Univ. of Toronto Press, 1963). See also D. Doroshenko, History of the Ukraine (Edmonson: Institute Press, 1939); Michael Hrushevsky, A History of Ukraine (New Haven: Yale University Press, 1941); and William \& D. Allen, The Ukraine, (Cambridge: The Univ. Press, 1940). 
The new Poland included about 4,000,000 Ukrainians. They were a majority of the population of eastern Galicia (until 1918, an integral part of the Austrian empire) and Volhynia (until 1917, an integral part of Imperial Russia). They considered themselves Ukrainians, had their own language, and were educationally and culturally somewhat behijd the Poles, Russians, and Austrians that had dominated them over past generations. In the formerly Russian sectors of eastern Poland, the Ukrainians held to the Orthodox faith, forced on them by the Russian Czars, Nicholas I and Alexander II, while the Uniate faith was prevalent in most of Galicia. 55

The primary economic orientation of the Ukrainian lands was agriculture, with some of the best soils and growing climates in all of Europe. It was this great food potential that provided the agrarian base for the people and commanded the attention of the ruling classes of eastern Europe. Note, however, that the land ownership was substantially in Polish hands and the city populations of GaliciaVolhynia were principally Polish and Jewish. ${ }^{56}$

In the Galician provinces of the new Poland, the autonomy granted the area by Austria in 1867 had resulted in a Polish

55

Buell, op. cit., p. 33. The Uniate church was established in 1596 by Polish and Lithuanian interests in an attempt to combat Russian ties among the Ukrainians. It recognizes the authority of Rome but retains Slavic liturgy.

${ }^{56}$ Ibid., p. 274 . 
administration that attempted to "Polonize" Galicia at the expense of all things Ukrainian. In spite of this handicap, Ukrainian nationalism, in 1914, was alive and ready when World War I presented the opportunity for new growth.

The special problems presented by the Ukrainians were their majority position in the lands that made up Poland's leading agricultural area, and their kinship to the $30,000,000$ or more Ukrainians of the Soviet Ukraine. An added complication was the religious division between the Orthodox and Uniate Ukrainians and the religious opposition of all Ukrainians to the Roman Catholic Poles. The minorities of the new Poland made up more than $30 \%$ of the total population and presented the new state with wide-ranging interests and special problems. Unlike Czechoslovakia where there was little agitation for independence in the decades leading up to World War I (federation was the most expressed objective), ${ }^{57}$ Polish pre-war interests and history led the Poles only to independence and a restoration of their "historic lands" - lands that were historically that of a state of nationalities, not a Polish national state.

These were the minorities of Czechoslovakia and Poland on the eve of World War I - the Czechs, Slovaks, and Poles that were

57Robert Kann, The Multi-National Empire, 2 Vol., (New York: Columbia Press, 1950), Vol. 2, Chapter IV. This chapter documents this federation objective, using quotations from Thomas Masaryk. 
about to become rulers; the Germans and Magyars that were about to become ruled minorities; and the Jews, Ruthenians, and Ukrainians that were about to come under new political rule. Cultural nationalism, in varying degrees, was present in all of the se population groups, while political nationalism was awaiting only the opportune moment to surface. 


\section{CHAPTER III}

\section{THE MINORITY TREATIES}

Throughout World War I the minorities of Eastern Europe sensed the new political climate. Though the war was ravaging their lands and economies, the chance for recognition of individual nationalities was obvious, and the minorities were not idle. Polish interests and actions surfaced across Europe and in the United States. Between 1914 and 1916, Polish volunteer troops were in action against Russia under Joseph Pilsudski (later to become "the father" of Poland). In 1917, Roman Dmowski (the subsequent leader of the right wing National Democrats), became president of a Polish National Committee based in Paris with offices in London and Rome. Ignacy Paderewski, the world famous pianist and leading Polish representative at the Paris Conference, was very active in the United States on behalf of the committee. Finally, in 1917, a Polish army was formed in France, placing the Poles on both sides in World War I. ${ }^{1}$

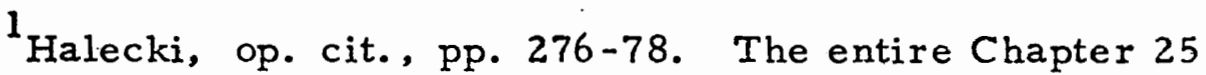
of this text is recommended for its detail of Polish activity during this period. 
Czecho-Slovak activity followed a similar course, with leaders such as Thomas Masaryk traveling constantly in support of their cause. Militarily, Masaryk estimated that there were 128,000 Czecho-Slovak troops in action at the time of the armistice, the most prominent force being the 92,000 men that made up the $\mathrm{Czech}$ legions in Russia following the appearance of the Provisional Government. $^{2}$ From Britain, France, and the United States, came support for special consideration of the Jews of Eastern Europe as well as both general and specific support for the Czech, Slovak, and Polish independence movements. 3

The new growth of nationalism was suddenly and dramatically accelerated on January 18, 1918, when President Wilson presented to a joint session of Congress his now famous "Fourteen Point Program for Peace. " 4 A careful reading of Wilson's entire text is necessary for a full understanding of its impact on the many.

${ }^{2}$. W. Seton-Watson, op. cit., pp. 298-305. Chapter XV of this text details the great political and diplomatic activity of the $\mathrm{Czech}$ and Slovak leaders and should be read with the cited Halecki text to appreciate the extent of the total minority activity by the time of the Paris Conference.

\section{${ }^{3}$ There were many shades of opinion among the Allied} Powers but no serious voices were raised in opposition to a new Poland and Czechoslovakia. The United States was a stronghold of most movement; note the "monster meeting" held in New York City on Sept. 15, 1918 in support of Polish, Czech, Slovak, Jugoslav, and Romanian causes. R. W. Seton-Watson, op. cit., p. 306. 
concerned nationalities. To an emigrant Czech in the United States, or a Pole in Paris, or a Slovak struggling for a Slovak school in his home town, or perhaps to a member of any of the minorities, concerned over preservation of perceived nationality, Wilson's words heralded a new era. The President denounced "private understandings," and pleaded for "strict observance of the principle that in determining all such questions of sovereignty, the interests of the populations concerned must have equal weight with the claims of the government." He also called for a "readjustment of frontiers along lines of nationality," insisted that "relations of Balkan States be determined by historic lines of allegiance and nationality, "and favored an "absolutely unmolested opportunity of autonomous development." Finally, he committed the United States and himself to "an independent Polish state," and called for "an association of nations to guarantee political independence to great and small states alike."

Not as well publicized as the Fourteen Points, but adding emphasis to his position, were certain of Wilson's speeches and earlier communications regarding the changing scene as he saw it. The most famous of these was his speech of February 11, 1918, which strongly re-affirmed the principle of self-determination. 5

${ }^{5}$ Robert Lansing, The Peace Negotiations, (Cambridge: Riverside Press, 1921), p. 317. The speech of February 11, 1918, gave special emphasis to the interests of people and promises, stating "they were not to be chattels and pawns in a game ... of 
According to Stephen Bonsal, Chief Interpreter for the American delegation, Wilson's cable to the Council of Workers and Soldier Delegates in Russia in 1917 was even more inspiring to the East Europeans than the Fourteen Points. In it the President solemnly stated that, "We are fighting for no selfish object but for the liberation of peoples everywhere from the aggression of autocratic forces. $" 6$ In these and many similar pronouncements, the Czech and Pole and Slovak and Croat - indeed, people everywhere - heard it all as a loud and clear recognition by the United States of his "right of self-determination."

It made no difference that England was in general opposition to the whole idea of a division of Eastern Europe into new small states, or that France was holding to the general principle of might makes right, ${ }^{7}$ or that there was strong disagreement within the

the balance of power." The speech also recognized the great importance of "national aspirations."

${ }^{6}$ Stephan Bonsal; Suitors and Supplicants, (New York: Prentice Hall, 1946), p. 284. The full quotation is, "The day has come to conquer or submit. If the forces of autocracy can divide us, we shall be overcome. If we stand together, victory is certain and also the liberties which only victory can secure . . . We are fighting for no selfish object but for the liberation of peoples everywhere from the aggression of autocratic forces."

7 This brief statement of the positions of England and France is the author's interpretation, resulting from the study of the selected bibliography texts. 
United States over the Fourteen Points. ${ }^{8}$ What the minority member knew, was that the President of the land of the free (America), to which thousands of his family and friends had fled over the last fifty years, had endorsed the principle of self-determination. By the time the Paris Conference was convened on January 25, 1919, the combination of the collapse of the empires and the growth of nationalism in the climate of "self-determination" had turned the mission of the conference, as regards Eastern Europe, from any thoughts of "should we or should we not" to an acceptance of a new order, and concern only with final shape and understandings. But, of course, it was not that easy. Being in favor of political democracy (selfdetermination) still left open the question of economic and social democracy. Here then was the problem to ponder in Paris - how to apply the principle of self-determination to Eastern Europe in a way that gives each new entity a reasonable chance for long life?

\section{CONFERENCE ORGANIZATION AND PRINCIPALS}

While the concern of this thesis is only with that part of the Conference that dealt with the new states of Czechoslovakia and Poland and the specific minority problems of each, attention must be

${ }^{8} \mathrm{~A}$ good example of this. United States opinion is found in a Kansas City Star editorial of November, 1918, written by Theodore Roosevelt and condemning the whole conciliatory approach expressed by Wilson. 
given to both the organization of the Conference and a look at the personal positions held by the three primary personalities: Lloyd George, Clemenceau, and Wilson. The early organization of the Conference was built around a central Council of Ten with representation from all the "Allied and Principal Powers." However, for many logistical, diplomatic, and pragmatic reasons, a Council of Four (United States, Great Britain, France, Italy) was organized on or about March 24, 1919, and soon that became an unofficial Council of Three as Italy stepped back over the debate on her own territorial interests. It was this Council of Three - Lloyd George, Clemenceau, and Wilson - that made the decisions in the minority matters, and to whom the seemingly endless pleas of the "suitors and suppliants" of Eastern Europe were presented.

Who were these men that held the fate of the Eastern European peoples in their hands? David Lloyd George, (1863-1945), was a skilled parliamentarian and an outstanding war leader 10 but had no qualifications for the assignment that involved "re modeling the world." 11 It appears that Lloyd George had three major handicaps for this role as peace-maker. First, he was

${ }^{9}$ Bonsal, op. cit., p. xi.

$10_{E}$. J. Dillon, The Inside Story of the Peace Conference, (New York: Harper and Bros., 1920), p. 62.

11 Ibid., p. 62 . 
totally tied to Britain's interests as a world power - her colonies, her markets, and her protective wrappings of sea power and alliances. Second, he was an empire advocate, and as such, held a skeptical view of the whole subject of small nations and "selfdetermination." The common quotation used to support this opinion is his reference to "those miserable nations. "12 His third handicap was his lack of knowledge of the geography, peoples and history of Eastern Europe, possibly a reflection of his long standing lack of interest in areas except as empire pathways. 13

George Clemenceau of France (1841-1929), commonly known as "The Tiger," was a Frenchman to the hilt. He loved France and hated her enemies. Being personally expert in European power politics, he was determined that Germany would never again march over France, and was equally determined that France was to be the dominant power on the continent. The handicap he carried into the negotiations regarding the new states and the minorities was his understandable orientation to French power and German contain-

12 Titus Komarnicki, Rebirth of the Polish Republic, (London: William Heinewon, Ltd., 1957), p. 275. From a Council of Four meeting on May 22, 1919, Lloyd George is quoted as saying, "The Great Powers shall not allow the . small states to use them as cats-paws for their miserable ambitions."

${ }^{13}$ Dillon, op. cit., pp. 62-66. 
ment. 14

Woodrow Wilson (1856-1924), then President of the United

States, was the complex member of the Council. About Wilson, there is no agreement. Ten historians seem to offer ten opinions, ranging from humanitarian on the up side, to naive dreamer, and on down to pure glory-seeker. It is not possible for this thesis to present Wilson as he really was. What can be done is to call attention to what Wilson was in the minds of the minorities of Easterp Europe. The words of Dr. E. J. Dillon, author, personal observer and commentator on the Peace Conference, vividly describe the Wilson image:

Never has it fallen my lot to see any mortal so enthusiastically, so spontaneously welcomed by the dejected peoples of the universe. His most casual utterances were caught up as oracles. He occupied a height so far aloft that the vicissitudes of everyday life and the contingencies of politics seemingly could not touch him. He was given credit for a rare degree of selflessness in his conceptions and actions and for a balance of judgement which no storms of passion could upset... Wilson was confronted with an opportunity for good incomparable vaster than had ever before been within the reach of man. 15

${ }^{14}$ It seems ironic that Clemenceau, The Tiger, who was widely recognized as true blue to French interests, should have been defeated in the following French elections by a coalition that criticized him as "soft" on Germany. See David Lloyd George, Memoirs of the Peace Conference, 2 Vol., (New York: Howard Fertig, 1972), Vol. 2, pp. 911-12.

${ }^{15}$ Dillon, op. cit., p. 90. While Dr. Dillon's description is 
That Wilson was out of step with the American electorate is well established. Evidence of that position is found in his party's defeat in the 1918 elections, the strong home front campaign against his efforts to commit the United States to moral, economic or military positions, the defeat of the treaties in the Congress, and finally, his defeat in the 1920 presidential election. However, he was at the Conference in 1919, and he was the champion of "self-determination."

\section{THE DEVELOPING MINORITY CONCERN}

It is essential to bear in mind that neither Czechoslovakia nor Poland was "created" at the Conference. Both countries were recognized by the victorious Allies as post-war necessities and, via emigrant and native efforts, formally recognized as national entities prior to the convening of the Conference. ${ }^{16}$ The Conference concern then, was with the final boundaries of the new states. The boundary discussions involved vast numbers of people from many national minorities. With the banner of "self-determination" carried by every minority group, the Conference concern was necessarily expanded to the future of each of the significant minorities. This led to the

very dramatic, his vivid picture of the Wilson image among the people of Europe is well supported by others.

${ }^{16}$ The independence of both countries was proclaimed before the Conference; Czechoslovakia on October 28, 1918, and Poland on November 11, 1918. 
development of the Minority Treaties. The treaty story, however, started with the finalizing of the Czechoslovakian and Polish boundaries.

The Czechoslovakian boundary decisions centered on two main areas. The first was the Bohemian Basin with Prague more or less at the center. In and around this basin lived a large AustrianGerman population. There were about 2,100,000 Germans in Bohemia, with a majority in several Bohemian districts, and they were all about to come under the rule of about $4,100,000 \mathrm{Czechs}$. The objections of these Austrian-Germans to their pending new minority stalus were long and loud and they are presented in detail in the Lloyd George memoirs. ${ }^{17}$. The heart of the protest was the flagrant violation of the principle of self-determination, carrying with it the threat of continual conflict. The requested solution was for the German majority districts to remain a part of Austria, a practical impossibility if one checks the geography of the basin. The Czech case was presented to the Council by Dr. Edward Benes, Minister for Foreign Affairs and future President of the Republic, and is again found in detail in the Lloyd George text. ${ }^{18}$ The part of the Czech case relating to the German question was based on

17 Lloyd George, op. cit., Vol. 2, pp. 613-15. 18 Ibid., Vol. 2, pp. 603-12. 
historic grounds (the restoration of the historic lands of the Crown of St. Wenceslas that pre-dated the German colonization of later centuries) as well as on strong economic grounds. It was the latter contention that prevailed, for the existence of the Bohemian Basin as an economic entity could hardly be denied. While understanding fully the violation of the bare words, "self-determination," the Council recognized the necessary economic modification of that phrase. The vote for the bistoric boundaries was unanimous. However, a personal quotation of Lloyd George is relevant, albeit in retrospect:

The result was the recognition of the polygot and incoberent State of Czechoslovakia, and the incorporation in the State of hundreds of thousands of protesting Magyars and some millions of angry Germans. The angrier they became the less consideration they got from the Czech government. Hence the present trouble. 19

The second major Czechoslovakian boundary problem involved the southern Slovak-Hungarian boundary. 20 As one moved south in Slovakia, the Magyar concentration increased, as did Magyar

\section{${ }^{19}$ Ibid., Vol. 2, p. 612. These Iloyd George memoirs} were first published in 1939. The "present trouble" refers to the Hitler movements of the late 1930s.

${ }^{20}$ R. W. Seton-Watson, op. cit., Pp. 327-28. There was a third disputed area on the Polish border. The Duchy of Teschen was the subject of considerable Conference discussion. The final decision created most of the Polish minority listed in Appendix C. 
domination of the administration of the area. Still further south there was a large Slovak population living within the homelands of Hungary. So where to place the new boundary? Again, economics had to be applied. The city of Pressburg (Bratislava) on the Danube was a Magyar city but its hinterland in Slovakia was heavily Slovak. It was also the only Danube access for the new state. The Conference therefore awarded Bratislava to the Slovaks. Other cities and towns that were determined to be Magyar, with Hungarian hinterlands, went to Hungary. As the boundary decisions progressed, it became apparent that great numbers of people would, as in Bohemia, necessarily come under a political rule not of their choosing.

In addition to revealing unavoidable exceptions to the principles of self-determination and nationality, the Czech actions in the various meetings also started to show some behavior patterns of a minority turned majority. The Czechs appeared to be out for all they could get. This was perhaps most apparent in their claims for a "corridor" that would run from Bratislava, south through Hungary, to St. Gothard on the Yugoslav border. This was 120 miles long with perhaps $80 \%$ of the population German or Magyar, but deemed a "strategic, political, and economic necessity." 21 While the claim

21

Lloyd George, op. cit., p. 603. However, this was not a claim born of the Conference. Masaryk had seriously discussed this idea years before as the new state seemed a possibility. 
was rejected, it served notice on the Council that the former minority was not adverse to extending its new political power over new minorities.

In addressing the Polish boundary question, the Council was powerless to deal with the eastern boundaries at that time. Those eastern lands involved Russian areas and Russian policies and had to await the outcome of the Russian power struggle. By 1920, this tense situation erupted in the Polish-Russian war and a final settlement did not come until 1921.

The German-Polish boundary discussions saw the Poles wanting to go as far west as the last home of the last Poie, regardless of how many Germans were caught in the net. The Germans pleaded for exactly the reverse. ${ }^{22}$ The boundary commission of the Council ${ }^{23}$ tried very hard to come up with a boundary that was based on primary ethnic emphasis, necessarily modified by economics, security, and tradition. Unfortunately, the final boundary still left 1,000,000 Germans in the new Poland and an estimated 1, 500, 000 Poles in

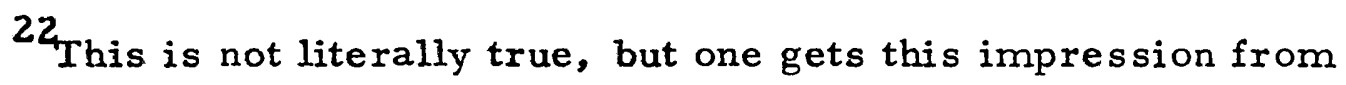
studying the claims and counterclaims. For a detailed review of this heated boundary debate, see Komarnicki, op. cit., pp. 313-49.

${ }^{23}$ Edward M. House, Charles Seymour, ed., What Really Happened at Paris, (New York: Charles Scribner's Sons, 1921), pp. 95-96. The commission consisted of representatives of the Big Four, two delegates from each country. The European delegates were professional diplomats and the Americans were oriented more to fact-finding than diplomacy. 
Germany.

Despite the Ukrainian majority in eastern Galicia, the Poles claimed all of Galicia for the new Poland. With the fluid Russian situation, the Poles sought to secure the Galician claim by military occupation of the area. This occupation was described by

Paderewski in his presentation to the Council as "not an offensive but a defensive advance. " 24 Offensive or defensive, this Polish occupation of Galicia, together with the Council agreement that some part of Galicia should be returned to Poland, brought about 4, 000, 000 Ukrainians under Polish rule. 25

In setting the boundaries for the new states, the minority problems became apparent. Czechoslovakia and Poland existed but with the necessary sacrifice of self-determination for millions of their new inhabitants. This new problem, the rights of the newly created minorities, was never anticipated at the opening of the Conference, and was complicated by the lack of Conference delegates that were familiar with these minorities. As the weeks went by it appeared that the new minorities included many threatening situations. In Poland, the Germans and Ukrainians were seen as

\section{${ }^{24}$ Iloyd George, op. cit., p. 644.}

${ }^{25}$ The 4,000,000 total includes the Ukrainians that were in the formerly Russian sectors that came back under Polish rule by the Treaty of Riga, signed in 1921 between Poland and the USSR. 
bitter enemies of the Poles, and the Jews as a distinctly alien element. In Czechoslovakia, the Germans and the Magyars presented severe hurdles to peaceful citizenship, while the Ruthenians had been attached to the new state with the intent of autonomy, not assimilation. None of these people wanted new rulers. It was the Peace Conference that imposed new rule on them. It was therefore logical and even required, in the minds of the conferees, that the Conference had an obligation to guarantee the minorities certain basic rights and privileges. Totally relying on the goodwill, benevolence, good intentions, or even future constitutions of the new states was believed by the Conference to be inadequate.

This mood of responsibility was fueled by the parade of special interest delegations that descended on Paris. In answer to the self-determination bell, they came from everywhere. In addition to the Poles and the Czechs, there were Red and White Russians, Arabs and Zionists, Montenegrins and their eternal enemies from Albania; Italians, Croats, Slovenes, Serbs, Macedonians; Ukrainians and Slovaks. $^{26}$ They came to be heard. From Poland came Paderewski and Dmowski; from Czechoslovakia came Masaryk,

${ }^{26}$ Bonsal, op. cit. The entire Bonsal text is a review of this parade, with considerable detail on the special pleas, apparent motivations, and aspirations. See also John Thompson, Russia, Bolshevism, and the Versailles Peace, (Princeton: Princeton Univ. Press, 1966), and Arnold D. Margolin, Russia, the Ukraine, and America, (New York: Columbia Univ. Press, 1946). 
Beneš, Stefanik, and the priest, Father Andrej Hlinka; from Romania came Ion Bratianu who was to be a leading minority spokesman; from Jewish communities came leaders of AngloSaxon, Eastern and Western Europe groups; from the Ukraine came delegates of Simon Petliura, and there were many more. 27 In one form or another, they wanted their version of control of their own destinies. Each had found what he wanted in Wilson's Fourteen Points. Some came in peace. Some came in fear. Some came in obvious search of a chance to dominate their neighbors as they were once dominated.

They were heard. Slowly, and by any staff member or principal that would listen, they were heard. Unfortunately, there was no procedure established to produce any action out of the pleas. No one at the Conference had any assignment to even listen, let alone recommend. $^{28}$ The awareness of a need for some action was accelerated by the rapidly passing weeks and approaching deadlines. Out of this pressure, came the Council decision to form a Minorities Committee, chaired by M. Berthelot of France, with membership from Great Britain, France, and the United States

\section{Ibid. , see note 26.}

${ }^{28} \mathrm{H}$. W. V. Temperley, History of the Peace Conference of Paris, 6 Vol., (London: Institute of International Affairs, 1921), Vol. 5, p. 123. 
(with Italy and Japan added later). 29

The Committee's function was to bring together the basic minority concerns, and, recognizing that the boundary decisions would leave most of them unresolved, address those concerns in the form of a treaty agreement. These Minority Treaties were to be between the Allied and Principal Powers and each of the new states. $^{30}$ In addition to a section on purely commercial matters, the primary section was to spell out the basic citizenship rights of all bona fide inhabitants of each new state. It was intended as a guarantee to each inhabitant that the new state could not adopt new laws that would leave them out of the new community. More positively, it was an attempt to make them a continuing part of the community. $^{31}$ The work proceeded rapidly. Started in late April, 1919, the treaty draft was presented to the Council on May 14th and sent to the Polish delegation and government a few days later. A similar treaty was drafted for Czechoslovakia and transmitted shortly thereafter.

29 Ibid., p. 124.

${ }^{30}$ In addition to treaties with Czechoslovakia and Poland, similar treaties were required of Yugoslovia and Romania based on territories assigned by the Conference that included large minorities.

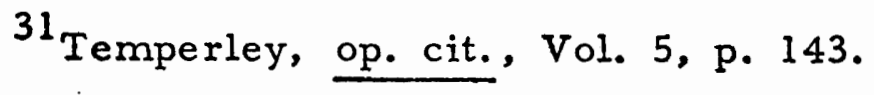




\section{AN EXAMINATION OF THE TREATIES}

The complete texts of relevant sections of both the Czechoslovakian and Polish treaties are included as Appendix $\mathrm{E}$ and $\mathrm{F}$. However, a review of the primary articles is a necessary preliminary to the understanding of the reaction of the new states. Both treaties are identical except for the special sections on Jews in Poland and on Ruthenians in Czechoslovakia.

Contrary to the views of the new states, the Council did not consider the treaty as any imposition on the sovereign rights of the new states. The Council maintained that it was the action of the Conference that resulted in the transferring of the minority groups from one rule to another. It was therefore both legal and proper for the Conference to spell out the conditions of that transfer and make the transfer subject to acceptance of those conditions. ${ }^{32}$ In keeping with this alleged legal basis and objective, the first Article of the treaty with Poland set up certain stipulations as "fundamental laws" that were to have precedence over any future state action. The second Article assured all inhabitants of Poland equal protection of life and liberty. A special mention was made of free exercise of any "creed, religion, or belief, if not inconsistent

32 Ibid., Vol. 5, Chapter II. The entire chapter develops this legal position in detail. 
with public order or public morals."

Article three through six then took up the matter of the nationality of the inhabitants. Everyone that was a "habitual resident" of the new Polish state as of the treaty date, automatically became a Polish national. Everyone that was born of parents that were "habitual residents" became a Polish national even though the children did not reside in the new state on the treaty date. Everyone born in Polish territory became a Polish national unless they were already nationals of some other state. The exceptions and options should be noted. Residents over eighteen years of age had the option of declaring some other nationality, with the provision that they would move to the state of that nationality within one year of so declaring. In such an event, they could retain title to immovable property, and transfer other property without restriction of duties. Non-residents could also renounce Polish nationality within two years of the treaty date.

Article six contained a government guarantee that the previous nationality options would not be influenced by any government action. Articles seven and eight recognized that nationals created by prior stipulations would include people of various races, languages, and/or religions. Equality before the law was guaranteed, as were civil and political rights. The free use of any language in public or private communication was guaranteed as well as the right 
to use such language before the courts.

Education was dealt with in Article nine. In districts containing a "considerable proportion" of Polish nationals using a language other than Polish, primary education was to be offered in the other language. The government could also make the Polish language a required subject. Such mixed districts were also promised an "equitable share" of public funds for educational, religious, or charitable purposes. There was an important exception -- all this applied to Germans only if they were residents of those areas that were German territory on August 1, $1914 .^{33}$

Articles ten and eleven contained special provisions regarding Jews. Local educational committees appointed by the Jewish community were to receive a proportional share of public funds for the support of Jewish schools. The Hebrew religion received special consideration as the Jewish Sabbath was exempted from any legal business, attendance in courts, or general or local elections.

In Article twelve, Poland agreed that all of the treaty stipulations affecting racial, religious, or linguistic minorities, were matters of international concern to be placed under the guarantee

33 It was argued that the many German residents of the eastern areas, and those that followed the troops during the war, deserved no special attention. 
of the Council of the League of Nations. Only the League Assembly could modify the stipulations, and the major powers agreed to approve any modification agreed to by a majority of the League Council. Poland acknowledged the right of any Council member to bring before the Council any actual or threatening infraction of the stipulations. Any dispute arising out of such a presentation was to go for resolution to the Court of International Justice in The Hague.

The treaty with Czechoslovakia deleted the Articles referring to Jewish considerations. It added, however, special provisions regarding Ruthenia. The Ruthenians were assured of autonomous treatment, consistent with unity of the state. They were to have their own Diet with full local powers, local Ruthenian officials "wherever possible," and equitable representation in the Czechoslovakian Diet. The only other difference in the treaties was a change in the educational commitment. Poland limited the minority language commitment to primary schools, while the Czechoslovakian version deleted the primary school reference and so applied the minority language rule to all public education. There is some speculation over the reasons for not making special provisions regarding the very large and powerful German minority in the Czech lands. The cited Temperley text reveals no record of special committee consideration. Temperley suggests that, first, the general provisions did the job, and that the problem was so funda- 
mental to ongoing Czech affairs that it was best to place maximum responsibility on the government itself. 34

\section{TREATY OPPOSITION AND DEFENSE}

Drafts of the treaties were forwarded to the new governments of Czechoslovakia and Poland in mid-May, 1919. The position of Czechoslovakia was almost the opposite of Poland. Very little serious Czech opposition was raised against the treaty, perhaps because the Czechs and Slovaks had what they came for, a new state, with "historic" boundaries. Their readiness to sign the treaty stemmed from several other sources as well. It was the Czechs that led the campaign for the new state. They had a cadre of qualified political, educational, and intellectual leaders, starting with Thomas Masaryk and Edward Beneš. Those Czech leaders had an immediate problem of unity with Slovakia, with whom there were great differences in culture, education, and the trappings of leadership. 35 In the east, the Czech leaders had no disagreement with the logic and necessity for special treatment of the Ruthenians. In the Czech lands were the Germans, a problem so large and so vital that

${ }^{{ }^{34}}$ Temperley, op. cit., Vol. 5, p. 146.

${ }^{35}$ R. W. Seton-Watson, op. cit., p. 323. The Magyars had completely dominated the administration of Slovakia. In pre-war years, less than $2 \%$ of administrative posts were held by Slovakidentified persons. 
the Czechs were impressed by its omission from the treaty, taking it as a vote of confidence that the Czechs could handle the German factor themselves. What was there to disagree with? Bias? They got their new state. Equity? They never seemed to raise the question. Sovereignty? Theirs was a new state. It was a composite of historic lands out of a dead empire. The Czechs had leadership, resources, and an opportunity. The combination was apparently good enough for them. The Poles, on the other hand, immediately raised questions of sovereignty, assimilation, and legality. There developed, accordingly, an active debate that built up to a formal opposition by the Poles at the May 31 st Plenary Session of the Supreme Council of the Conference.

The Polish case was argued by Paderewski. His attack revolved around three main points: his feelings regarding the bias of the three principal members of the Council, his view of equity, and the question of sovereignty. In claiming a Council bias, Paderewski referred to the British interests in maintaining an active Germany, which led to Lloyd George's siding with German interests in both Czechoslovakia and Poland. Clemenceau, as seen by Paderewski, looked upon Poland only as a buffer between Germany

${ }^{36}$ Temperley, op. cit., Vol. 5, p. 470. By February, 1920, Czechoslovakia had enactedits own Language Law (Appendix G) that went well beyond the Minority Treaty in detailing minority language and educational rights. 
and Soviet Russia, while Wilson, the champion of self-determination, came under suspicion of bias as he reverted to "might is the source of right" on one occasion. 37

The perception of equity played a major part in the Polish case against the treaty. As a new sovereign state, Poland's position seemed simple and proper. Poland wanted the same rules applied to all states. What rules? Basically, the principle of selfdetermination and the rights of minorities as spelled out in the Minority Treaty. Evidence of the great difference between the expressed desire of the Allied Powers for minority rights in the new states and the same rights in their own countries may be found in the drafting of the Covenant of the League of Nations. The original draft of the Covenant, prepared by Wilson, included an Article that recognized the probable future need for "territorial readjustments. -. by reason of changes in racial conditions and aspirations or social and political relationships, pursuant to the principle of selfdetermination. ${ }^{38}$ It made such territorial readjustments subject to a Delegate vote and it bound the Powers to "accept without reservation the principle that the peace of the world is superior in

37 Temperley, op. cit., Vol. 5, p. 130. The cited occasion was Wilson's speech to the Plenary Session of the Supreme Council on May 31, 1919.

${ }^{38}$ Iansing, op. cit., p. 93. 
importance to every question of political jurisdiction or boundary. 1 $^{39}$ Before presentation to the Commission on the League, the draft was revised into a simple guaranty to "respect and preserve the territorial integrity and existing political independence of all Members. ${ }^{140}$ In that form, without any references to self-determination or changes in racial conditions or aspirations, it went into the Treaty of Peace. The opinion was expressed by Robert Lansing, Wilson's Secretary of State, that the drastic revision was directly due to objections raised by the British Empire with a view toward their far-flung territories. 41 In spite of the Covenant revision, Wilson continued to promote the self-determination principle and the credibility gap, in the minds of the Poles, grew wider by the week.

The equity objections did not deal only with general principles. In two specific situations, the Poles alleged a gross inequity. First was the German minority in Poland that was about to come under the protection of the treaty, although the many Poles in Germany were given no such guarantees. In a Council meeting on the subject on June 17th, Wilson agreed with the Polish objections and stated, "It was a serious indictment that we were claiming more for the 39 Ibid., p. 93. 40 Ibid., p. 94. $41_{\text {Ibid. , pp. } 94-95 .}$ 
Germans in Poland than for the Poles in Germany. "42

The Jewish problem produced the second claim of inequity. The Polish view was centered on the citizenship of the Jew, claiming the Jew was a Polish citizen, should be treated like one, and should act like one. However, substantial outside pressures were present from British and American Jewish groups. These groups gave wide publicity to many anti-Semitic incidents occurring during the war years. Pointing to these incidents, they held to the general position that the Jews of Poland, based on Polish actions in recent times, must receive special consideration, above and beyond that accorded other residents. ${ }^{43}$ While the American and British Jewish interests were pushing hard for Jewish privileges, Wils on and Lloyd George were skeptical. Wilson expressed concern over "imparting to the Jews a corporate capacity" ${ }^{44}$ and Lloyd George agreed that Jewish school separation would "tend to create a separate nation of Jews in Poland rather than unity. " 45 Paderewski reminded the Council that the Polish partitions, which all the Allied Powers had denounced, were partially justified at that time

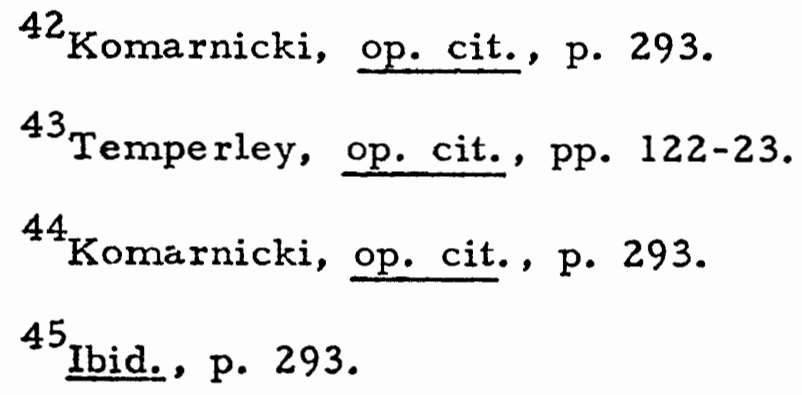


on grounds of religious minority protection, a historic remembrance that made the Poles nervous when viewing the Jewish demands. ${ }^{46}$ The final treaty Articles were an acceptance of the need for some special Jewish consideration, but far short of Jewish demands. Still, the mere mention of the problem in the Polish treaty alone, placed a certain anti-Semitic onus on the Poles that was not so placed on the other new states and territory assignments.

Bias and equity were major factors, but sovereignty was the core of the Polish opposition to the treaty. In the opinion of the Poles, as a sovereign state Poland had the same status as all other states. The Minority Treaty, not required of all states, was a major infringement on that sovereignty. The provision for special treatment of nationals, not required of all states, was a further infringement. Above all, however, the provision for the review of treaty infractions, or even threatened infractions, by the League of Nations upon the complaint of any member of the League, was the bitter pill that Polish leaders swallowed very reluctantly. It was the Polish contention that the presence of this external court of appeal would produce perpetual alienation of the minorities. In the opinion of the Poles, national harmony would never be achieved as long as alleged grievances could be routed to outside interests, circumventing 
Polish law and procedures. More important than the objections of practice and procedure was the basic contention that one sovereign League member could not be subjected to rules non-applicable to the others. That, said the Poles, was a denial of sovereignty, pure and simple. 47

The Council response to the Polish treaty objections was covered by Wilson's speech to the Plenary Session on May 31st, and by Clemenceau's transmittal letter that was sent with the treaty; to Poland. 48 Of major concern to the Council was the fact that millions of people were being transferred from one political rule to another without their consent. Since the self-Getermination banner was still flying over the Council chambers, a reconciliation of Councilintentions and actions was imperative.

Briefly, the Council had no alternative. There does not appear to be any record of any alternate boundary decisions that might have been made that would have substantially eliminated this minority problem. Mass resettlement of populations or creation of additional states was not considered as a viable

47 This is a summation of Polish opinions as presented in Temperley, op. cit., pp. 141-142, and Komarnicki, op. cit., pp. 291-301.

48

Ibid. The Wilson text is found on pp. 130-32 and the Clemenceau text on pp. 432-38. 
choice. 49 The new Poland was a fact. The need for a basic economic and social structure of the new Poland was essential. The resulting intermingling of the populations and the intertwining of economic interests created a Gordian knot. The solution, therefore, was a compromise. The compromise formed both Poland and the new minorities.

As a creator is responsible for his creations, so the Council was responsible for the welfare of the new minorities, and the new position of some old minorities. It has been noted that the Conference did not create the new states. The war was the creative catalyst, and the Allied Powers (Britain, France, United States) would be required to keep the peace. From the war's ruins, the Council built its case. It was by Allied Power action that Poland was born and populated. It was regrettable, but unavoidable, that the new population included large numbers of people to whom the rule of self-determination was being denied. The Minority Treaty became the substitute for self-determination, establishing the minority rights as "fundamental laws" to take precedence over any future

${ }^{49}$ On the question of mass transfers of populations, such as between Greece and Bulgaria at the close of World War I, and the transfers after World War II, the author could not find any evidence that the Conference ever considered such action as applicable to either Czechoslovakia or Poland. It seems likely that any mass transfer. would have been involuntary and thus a violation of self-determination. 
action of the new state. As such, the Treaty was meeting a Conference obligation that was an integral part of the act of creation. On the specific question of equity, the Council's position was never officially stated, but was unofficially obvious. The Paris Conference was not convened to re-make the entire world. It was called to conclude a peace with the defeated Central Powers that included new arrangements for certain areas previously under Central Power control. By no stretch of the imagination, did the Conference have either authority or intention of setting up behavioral rules and regulations that would also apply to American Blacks or Catholics of Northern Ireland, or Basques of Spain, or any other existing state's problems. Accepting the idea of world-wide enforcement of the principles involved in the Minority Treaties was out of order. However, the inability to accomplish a total task does not obviate the need to get started with a solution. Technical and admitted inequity was not an acceptable reason for inaction, a position understood by the Czechs and either not understood or ignored by the Poles.

Sovereignty was the remaining question. The League of Nations was not set up as any guarantor of "free or constitutional government or guaranteeing liberties of any kind. ${ }^{50}$ Its basic 50 Temperley, op. cit., p. 140. 
function was to guarantee the provisions of certain treaties entrusted to the League by mutual consent of the covered states. This was not the usurpation of sovereignty but rather the carrying out of an assigned task. The Polish contention was that the minorities would view the League as their sanctuary, to the exclusion of the Polish government, perpetuating particularism, not unity. The Council counter was the contention that the knowledge of the existence of an independent jurisdiction would allay early fears and promote eventual unity.

The objections of the Polish Delegation did result in a number of modifications in the original draft. The Treaty Committee also revised certain wording, but in the main, the original principles were "rigidly adhered to. ${ }^{51}$ On June 28, 1919, the Minority Treaty with Poland was signed at Versailles. On September 10, 1919, the Minority Treaty with Czechoslovakia was signed at Saint-Germain-en-Laye. Many men had labored long to bring about a new order of things in Eastern Europe. New states were recognized that did follow primary nationality lines. Most of the people of Eastern Europe were under a rule of their own choosing. The new minorities had their rights spelled out in treaty form, the first such detailed written guarantees in the history of western

\section{${ }^{51}$ Ibid., p. 132.}


civilization. ${ }^{52}$ How effective the new minority rights proved to be is the subject of the next chapter.

52 There have been many prior mentions of minority religious and political rights but nothing that compares with the detail of the Minority Treaties and the fact that the treaties were sponsored by all the Allied Powers. 


\section{CHAPTER IV}

\section{MINORITY RIGHTS: ACTIONS AND RESULTS}

The minorities of the new states presented major problems to the new rulers. The Minority Treaties, in recognizing these problems, detailed certain basic minority rights and set up a specific procedure for minority grievances. The leaders of both Czechoslovakia and Poland proclaimed the intentions of the new states to honor minority rights, with or without the treaties. With the problems recognized, and with treaties and good intentions guarding the minority rights, what was the relationship between the rulers and the ruled in the years between the two World Wars?

\section{THE CZECHOSLOVAK MINORITIES: 1919-1938}

The Czechs and Slovaks debated the proper description of the new state from its very beginnings. Was the state a "national state" or was it a "state of nationalities ?" ${ }^{1}$ Early legislation

1 Both Benes and Masaryk accepted the "state of nationalities" description. Speaking of the new states of Eastern Europe, Beneš stated, "It was not possible to form these... states as if they were national states; it was not possible to.. exclude from them all minorities." See HCR, op. cit., pp. 176-77. 
confirmed the latter designation. The Constitution of 1920 incorporated all the provisions of the Minority Treaty and was regarded a's a "thoroughly liberal constitution following Western models." A "Language Law" was enacted in February, 1920 (Appendix G). The law designated Czech and Slovak languages as official tongues, and specifically provided for complete commercial, public, and legal use of minority languages in all districts having a racial minority of at least $20 \%$. The law also specified the "mothertongue" for all instruction in all minority schools; it was, in fact, a strong extension of the Minority Treaty.

But while the Constitution and the Language Law established legal and leadership concern for the minorities in Czechoslovakia, that concern was neither shared nor accepted by the population at large. ${ }^{3}$ According to one observer of the scene, the bureaucracy "frequently behaved as if the State had been created for Staatvolk only and that all others were to get what was left over." ${ }^{4}$ This review of Czechoslovak and Polish minorities will pay attention to both the spirit and the letter of the laws, as well as to the following

\section{Ibid., p. 173.}

${ }^{3}$ On the political front, the National Democrats, headed by Karel Kramar, a strong anti-Bolshevik and political opponent of Masaryk, promoted the "National State" concept. See Hugh Seton-Watson, op. cit., p. 173.

${ }^{4}$ HCR, op. cit., p. 177. 
questions. How did the minorities fare under the new rule politically, culturally, and economically? Also, and perhaps the most important of all, what were the attitudes of the minorities toward the new rulers?

\section{The Czechoslovak Germans $^{5}$}

In the Czech lands of Bohemia-Moravia, the 1921 census showed the Germans were almost one-third of the population. ${ }^{6}$ They were the former rulers of the land and the leaders of industry and administration. They exercised a "dominating influence in the State. ${ }^{7}$ After reviewing the prominent German position, the Conference Committee on New States determined that, "It is clear that the prospects and perhaps almost the existence of the new State will depend on the success with which it incorporates the Germans as willing citizens. ${ }^{8}$

Politics came first. Things got off to a bad start when the Czechoslovak National Assembly started the draft of the new

${ }^{5}$ Note the change in reference from "Germans in Czechoslovakia" to "Czech-Germans" and the similar use for the other minorities. This is not a description of what was, only of what was the hope of many.

${ }^{6}$ See Appendix C for exact figures and concentrations. 7 7 HCR, op. cit., p. 172.

8

Ibid., p. 173. 
constitution. The Assembly was made up entirely of Czechs and Slovaks; no Germans, Magyars, or Ruthenians were included. In spite of the agreed liberal nature of the constitution, the excluded groups could, and did, claim discrimination. When the first elected parliament convened in May, 1920, all of the several newly formed German parties were in opposition to the government. However, only the German Nationalists looked to separation while the rest of the parties pressed for various degrees of autonomy within the State. Working within the State framework, Germans assumed influential government posts within a few years. By 1926, Germans held the ministries of public works and justice and in 1929, the Ministry of Social Welfare. Throughout the civil service, they did not do too well, but for predictable reasons. A trait of the bureaucracy as well as individuals was, and still is, to flock together, to appoint your own kind, and so the Czechs appointed Czechs. A more defendable ${ }^{9}$ reason was the language problem. Few Germans spoke Czech while most Czechs spoke German and bi-lingual ability was a civil service asset.

In spite of problems of representation and civil service, German voters appeared to demonstrate a preference for working

9 Use of the term "defendable" does imply an undesirability of the human tendency to "flock together." The tendency is a fact. Whether or not it is undesirable will be left up to the reader's personal opinion. 
for a better voice within the state. Irredentist tendencies were apparently in the minority. Using the Czechoslovak Statistical Yearbook, J. S. Bruegel, a British historian and author, divided the German parties into "activists" (working for participation) and "negativists"(working for separation). The elections of 1920, 1925, and 1929 all showed a $75 \%$ or better activist majority. ${ }^{10}$ Then came 1933. As Adolph Hitler came to power, in the Weimar Republic, so did an obscure teacher by the name of Konrad Henlein in Czechoslovakia. $^{11}$ Riding a tidal wave of German national fanaticism, Henlein formed the Sudeten German Party. The proclaimed party goal was autonomy for Sudeten Germans, not secession. However, as Hitler became more aggressive, so did the Sudeten German Party. Entering the 1935 elections and clearly classed as "negativist," the Sudeten German Party polled about 70\% of the German vote, a direct reversal of prior years' results. Statistically and politically speaking, Czech-Germans up to 1933 worked towards a better position with the Czechoslovak state. The sudden support of Henlein, however, indicates the possibility that the cooperative attitude prior to 1933 reflected resignation to the best

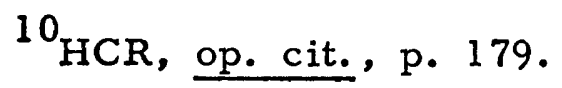

${ }^{11}$ R. W. Seton-Watson, op. cit., pp. 351-54. These pages detail the background and rise of Henlein and his Sudeten party. See also the Bruegel study, HCR, op. cit., pp. 182183. 
available situation, rather than acceptance.

The Language Law strongly re-enforced the Minority Treaty in the area of education. Bruegel has made some descriptive comparisons between Czech-Slovak schools, German schools in Czechoslovakia, and German schools in Germany. ${ }^{12}$ It shows the CzechGerman schools were superior to schools in Germany and the equal of Czech-Slovak schools, using "pupils per class and per teacher" as the statistic. Further support is found in higher education where Germans received a more than proportionate share of Czechoslovakia's higher education budget. ${ }^{13}$

On the economic side, the German in Czech lands started with a prominent position in state administration, industry, and agriculture. He might have had cultural or political ties to Germany or Austria but his economic interests ran to the Czech markets. The German position in the private economic sector simply rose or fell with the economic fortunes of the state. Those fortunes had a difficult time in the first few years as the industry of the new state had to adjust to a changing market-place. 14 Things improved in the later 1920s, only to crash with the rest of the world in the Great

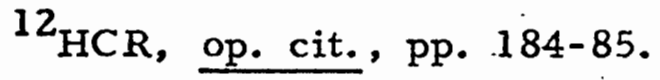

13

Ibid., p. 184.

14 The primary pre-war markets of Bohemia were Germany and Austria -- both were severely reduced in the early post-war years. 
Depression. No evidence of economic discrimination is found in the statistics of the depression years. From 1930 to 1935, the government made unemployment payments to German trade unions in greater per worker amounts than to the Czech and Slovak unions, due to a higher wage structure of the German areas. Also, special relief in kind was nearly equal in total value and favored the Germans in per capita grants.

The Czechs kept the political, cultural, and economic roads open for the German minority. What did the Germans think about their new minority status ? ${ }^{16}$ While some Czechs will look back and see only a paradise of offered love and affection, a German loyalist will view the same scene and report exactly the reverse. ${ }^{17}$ Where does the truth lie? Part of the truth remains hidden beneath the

\section{${ }^{15}$ HCR, op. cit., p. 186.}

${ }^{16}$ Remember that the Czech-Germans were always a statistical minority in the Czech lands, even though a political and economic majority in the pre-war years. Also note that these Germans were never part of the German empire. Their background and fortunes had been tied to the Austrian empire.

17 The Slavonic Review, Vol. 14, pp. 295-320. This periodical contains an excellent example of these contrasting views. Following the Henlein victory in the 1935 elections, the Review editors solicitied opinions on the Czech-German minority situation. The German view is by a German Bohemian Deputy and a leader of the Sudeten German party. The Czech view is by a Dr. Emil Sobota, prominent in Czech politics. The German literally tears the alleged $\mathrm{C} z e c h$ benevolence apart, citing numerous statistical "proofs." The Czech admits a problem but alleges the problem stems from German unwillingness to use the offered opportunities. 
debris of the Great Depression and the boots of the Nazi Stormtroopers. The truth may also lie in the opinion of Dr. Otto Lechner, a. Czech industrialist and political writer, when he stated, "The treatment of the minorities in our country was good - it could have been better. 18

The Caechoslovak Magyars

There was no such thing! As with the Germans, the Magyars went from rulers to ruled. As rulers, the pre-war Magyars in Slovakia controlled the channels of government, commerce, education, and culture. ${ }^{19}$ With the change in status, some Magyars refused to serve the new masters and withdrew to the newly-shaped Hungary. The 1921 census shows that about 750,000 stayed on. $^{20}$

Initial Magyar reaction to the new rule was antagonistic. While Magyars were not invited to the initial Constituent National

$18_{\mathrm{HCR}}$, op. cit., p. 187 . The quotation is from Lechner's book, As We Saw It in Prague, (London; 1942), p. 116.

${ }^{19}$ C. A. Macartney, Hungary and.Her Successors, (London: Oxford Univ. Press, 1937), p. 91. Macartney suggests that the Magyarization of Slovakia was not necessarily a one-way street. He stated, "The denial of national culture is only oppressive when it is felt to be oppressive." The Slovak could see great advantages in joining the Magyar society and did so in great numbers.

${ }^{20}$ With the re-settlement of the Germans, the extermination or emigration of the Jews, and the transfer of Ruthenia to the USSR, the Magyars are the only significant minority remaining in Czechoslovakia today. 
Assembly (to form the new constitution), it is the opinion of C. A. Macartney, eminent scholar and authority on Eastern Europe, that the Magyars would not have attended even if invited. 21 The new Constitution extended full political rights to all nationalities. The basic rights of party formation, secret ballot, and freedom of political expression were all extended to the Magyars, and gradually, they did avail themselves of these rights. Freedom of vote, speech, and movement, however, does not necessarily produce political results. By a system of Czechoslovak gerry-mandering, districts were arranged to reduce concentrations of Magyar votes. In certain Magyar-controlled cities, the burgomaster was appointed by the government instead of elected as in the non-Magyar cities. ${ }^{22}$ The sum total of all this was political freedom but no political power.

The Language Law of 1920 has been generally regarded as a very positive step towards minority rights. In Slovakia, one can find some interesting applications. The Magyar language was

${ }^{21}$ Macartney, op. cit., p. 152. While Macartney is cited in this case and in a number of following instances, he is considered to be a leading authority on the Magyars and their lands. The reader is referred to the previously cited texts by R. W. Seton-Watson for additional support of the Macartney citations.

22 Ibid., p. 153. 
dominant in many regions of Slovakia. ${ }^{23}$ This was the result of generations of controlled education and the obvious commercial advantage, or even requirement, of speaking Magyar. Official counts on which the 20 percent rule would be applied, were based on "stated nationality," not language. Thus, the large number of Magyar-speaking Germans, Jews, or Slovaks were linguistically not counted. By this system, one could be in a community with almost total Magyar tongue used in public places and still be faced with nothing but Czech-Slovak signs and legal language. 24

Closely tied to politics and language were the matters of justice and the civil service. As to justice, it is agreed that the linguistic privileges of all minorities were "scrupulously observed" 25 as was the Constitutional guarantee of equality before the law. The civil service presented a situation somewhat different from the CzechGerman result. The decline in Magyar posts was very great. Many Magyars either refused to serve, or were so openly hostile

23"Dominant" in this case refers to the language of the educated and commercial society. Among the peasant families (the majority of the Slovak population), the Slovak language lived on. See R. W. Seton-Watson, Racial Problems in Hungary, (New York: Howard Fertig, 1972), p. 437, for detailed statistics on the Magyar dominance of Slovak education. Hereafter cited as RWSW.

${ }^{24}$ Macartney, op. cit., p. 157.

${ }^{25}$ Ibid., p. 158. 
as to require their release. ${ }^{26}$ These vacancies were initially filled by Czechs for there was no Slovak cadre of eligible public servants. Czechs in Bohemia surely sensed the need for living with the Germans, but it is probable that the Czech in Slovakia, faced with an angry Magyar and an unhappy Slovak, countered in kind.

The Czechs had two major educational tasks in Slovakia: to raise the literacy level of the Slovaks, and to provide proper educational opportunities for the minorities. They accomplished both. The minority position was well stated by Macartney, "The position for all minorities is most satisfactory as regards elementary education, where a genuine effort seems to be made to ensure that every child is instructed in its mother-tongue. " 27 Supporting this statement are school statistics showing proportionate treatment of Slovak, Magyar, and German schools. ${ }^{28}$ Macartney also commends the division of public funds for education. While the Czech administration made Magyar education proportionally and linguistically correct, the fact remained that the actual number of Magyar

${ }^{26}$ Joseph Rothschild, East Central Europe Between the Two World Wars, (Seattle: Univ. of Washington Press, 1974), p. 119. Also see R. W. Seton-Watson, op. cit. p. 323. The Magyar civil service decline was estimated at $60 \%$, about twice as severe as among the Czech-Germans.

27 Macartney, op. cit., p. 166.

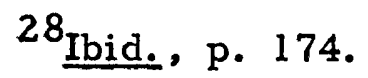


schools was reduced. From a total Magyar dominance of education, the Magyars went to proportionate sharing with all the other national groups.

Slovakia was an agrarian and semi-mountainous country. The principal land holdings belonged to the ruling Magyars, many of whom returned to Hungary. Their exodus facilitated land reform, meaning the expropriation of Magyar lands. It has been estimated that $80 \%$ of the expropriated land was Magyar owned, while over $90 \%$ of the re-distribution was to non-Magyars (Slovaks and Czechs). The new land was also "colonized" in strategic areas by Czechs and Slovaks in order to reduce Magyar concentrations. It has been alleged that such colonizing was deliberately aimed at any possible future boundary revision by establishing ethnographic claims. 29

A shift in financial institutions from Magyars and Jews to Slovaks and Czechs was inevitable, but in trade and industry, there was far less disturbance. Geography again entered in. The orientation of Slovakia is to the south, to Hungary. The mountains, the rivers, the downhill run to the Danubian Plain makes it so. The Magyars stood astride the channels of commerce, along with the

29Ihid., p. 174. Macartney is very sure of the Czech motive - to break up Magyar majorities. This policy was referred to in note 38 , Chapter II. 
Magyarized Jews. These owners were in a much better position to continue the southerly trade than any Czech replacements (and there were few Slovaks replacements available). The problem, however, was more in the lack of volume than the direction. An increasing population (the result of high birth rates and reduced emigrations), the geographically difficult east-west trade, and the diminishing Hungarian market added up to increasing hardships for all of Slovakia. Economic troubles were accelerated by an agricultural depression in 1927 that in turn touched off a Czech policy of autarky. The policy was to have the agrarian Slovakia-Ruthenia balance the more industrial $\mathrm{C} z e c h$ lands. An immediate result was the severing of Slovak-Hungarian trade, the very life-blood of Slovak economy. ${ }^{30}$ The markets of the Czech lands were not sufficient to make up the disruption, resulting in severe unemployment. Ironically, the Magyar workers were somewhat less affected than the Slovaks, as the Magyars were not only the more skilled workers but also had the advantage of working for Magyar employers. The economic problems faced by the Magyars were related more to the deteriorating economy than to discrimination.

Budapest is less than fifty miles from the Slovak border. The Magyars in Slovakia had been rulers for 1,000 years and were ${ }^{30}$ By 1931, exports to Hungary and imports from Hungary has both dropped to less than $20 \%$ of the 1929 level. 
not about to change in a decade or so. Most Magyars, from manager to peasant, were technically as well off under Czech rule as under the rigid Hungarian system. But old loyalties die hard. The Magyar perception of $\mathrm{Czech}$ rule paid attention more to the loss of authority than to the acquisition of new opportunity, a reaction similar to that of the Germans. Human nature seems to be the culprit. It may be that not everyone yearns for authority. However, almost everyone, once accustomed to the possession and use of authority, gives it up very reluctantly. Treaty rights and Czech actions to the contrary, a secret ballot plebiscite on return to Hungary would have drawn, in 1935, a vast majority of Czech-Magyar votes. ${ }^{31}$ The problem, the Magyar irredenta, had hardly been dented.

\section{The Czechoslovak Ruthenians}

The evaluation of any position must give attention to past progress as well as present weakness and so it must be in Ruthenia. Under Magyar domination for centuries, the 1919 population of Ruthenia was still identified as two-thirds Ruthenian. The Ruthenians were essentially mountain-peasants, illiterate, and, in some opinions, on the verge of total assimilation into Magyar nationality. 32

${ }^{31}$ Macartney, op. cit., p. 183. It is Macartney's opinion that the pro-Hungarian vote might have been $90 \%$.

$32_{R}$. W. Seton-Watson, op. cit., p. 324 . 
But Ruthenian nationalism was still alive. The Minority Treaty specified an autonomous government. Ruthenia was to have its own Diet, control of its own local affairs, local Ruthenian officials, and representation in the Czecho-Slovak Diet in Prague.

There is considerable criticism of the Czech failure to proceed with these political provisions. By 1935, there was no Ruthenian Diet or anything approaching autonomy. The Czechs had a pragmatic reply. In view of the unsettled conditions among the neighbors, any autonomous arrangement would be very vulnerable to demagogic or just plain incompetent leadership. ${ }^{33}$ To this leadership concern, a more political motive was added. Ruthenia, was logically a part of either Hungary or a new Ukrainian state. Early autonomy thus carried the danger of early separation. The Czech alternative was to provide a body of Czech leadership, as was done in Slovakia, partly for control and partly out of sheer necessity. Under that controlled leadership, the Czechs started active economic and cultural programs that were aimed at a society that could run itself, and remain loyal to the new state. Macartney's observations regarding this $\mathrm{Czech}$ administration are

${ }^{33}$ While this is a familiar objection of entrenched power viewing a newcomer, the accepted high quality of $\mathrm{Czech}$ leadership gives credence to the claim. See Hugh Seton-Watson, op. cit., p. 181 . 
very descriptive. ${ }^{34}$ He likens the rule to that of the British in India. He tells of Czech official quarters, clubs, shops, social networks, and of a Czech feeling of being on foreign duty, with the Ruthenians being the "natives." He also describes the $\mathrm{Czech}$ officials as "intelligent, honest, and devoted."35 The quality and the intentions of the Czech leadership were well above any previous Ruthenian experience. The Czechs also invested major funds in everything from roads to communications, to public health and education. Although the Treaty provisions for autonomy were not followed, the Czechs contended they were building the foundation for autonomy.

Education was a major requirement. Owing to the is olation and habits of rural life as well as the complete Magyarization of the schools, illiteracy was widespread. The first hurdle was the very basic choice of language. A new Ruthenian school might logically.use Great Russian, Ukrainian, or a local dialect. Confusion bred confusion and the result was a little of everything. Meanwhile, the schools were built. Within ten years, Ruthenia progressed from 600 schools and 1, 000 teachers to 800 schools and 2, 700 teachers,

${ }^{34}$ Macartney, op. cit., pp. 225-28. On this subject of Ruthenia, historians, including the renowned R. W. Seton-Watson, accept Macartney as the leading authority due to his personal contacts with the land and the people.

$35_{\text {Ibid., p. } 227 .}$ 
proportioned among the Ruthenians, Magyars, Germans, and Jews.

The many $\mathrm{Czech}$ schools were also heavily attended by the Jewish minority in preference to the linguistically confused Ruthenian schools. 37 The educational effort resulted in a major rise in literacy and in the cultural level of Ruthenia.

The familiar problems of the land-oriented society were present in Ruthenia. Serious overpopulation resulted from the combination of a high birth rate, restricted emigration, and an agrarian economy that employed almost $70 \%$ of the working population. 38 A further complication was the loss of the Hungarian markets that followed the 1927 Czech policy of autarky. In spite of the problems, the Czechs worked at improvements. The Magyar and the Jew had control of pre-war Ruthenian commerce. To get the Ruthenians into commercial activity, the Czechs assisted the development of Ruthenian commodity and credit cooperatives, as well as establishing a new Ruthenian bank group. 39

The record gives the Czechs generally good marks for their

36

Slavonic Review, Vol. 13, p. 377. Because statistics vary according to the statistician's rules, the quoted figures are approximations that are verified in other texts.

37 Ibid., p. 278.

38 Ibid., p. 376 .

${ }^{39}$ Ibid., p. 376 . From almost nothing in 1920 , ten years saw over 400 cooperative branches in both credit and commodity fields. 
minority efforts in Ruthenia. What did the Ruthenians think? The Ruthenians who were aware of the autonomy provisions of the Treaty were disappointed. Those who compared life under the Czechs with life under the Magyars were pleased. However, the Ruthenian who lost his job with the loss of Hungarian markets was doubtless angry. The basic ingredients of a successful union with Czechoslovakia were present, given the time necessary to make it all work. 40

\section{The Czechoslovak Jews}

The pre-war Jewish minority in Slovakia and Ruthenia was closely allied with the ruling Magyars, and with the ruling AustrianGermans in the Czech lands. As the Czechs took control of the government in all provinces, they welcomed support from any nonMagyar or non-German, the Jews in particular. Under Czech rule, the Jews enjoyed freedom of both religion and opportunity and became strong supporters of the new state. The pre-war ill-feeling toward the Jews that was found in Slovakia and Ruthenia seemed to disappear as the Slovaks and Ruthenians now saw the Jews somewhat more as citizens of the new state than as part of a Magyar ruling group. The special problems presented by the Jewish minority - the danger of anti-Semitism and the use of Jewish talent - were well on the road

40 Note that Ruthenia was annexed by the USSR in 1945 as part of the re-alignment of Eastern Europe. 
toward solution.

Overall, how did the Czechs meet their minority obligations?

All the cited texts indicate that they deserve high marks for observing the letter of the law. Before commenting on the spirit of the law, a reminder of the Czech situation is in order. The two dominant groups of pre-war central and eastern Europe were the Germans and the Magyars. Czechoslovakia had to contend with both of them. The Czechs also had the talent and desire to rule their own lands. During generations of being ruled by Germans and Magyars, the Czechs and Slovaks developed no love for these rulers. Perhaps that is part of the reason why observance of the spirit of the law was weak. That weakness showed up in the granting of political voice but never power, in the gerry-mandering of districts, and in personal ways such as the "foreign-duty" attitude of Czech officials in Ruthenia. There was a difference between the attitudes of Czech leadership and the attitudes of the Czech people toward the national minorities. The difference was understandable and showed signs of being resolved.

Overall, how did the Czechoslovakian minorities rate their situation? All evidence shows the Germans and Magyars remained Germans and Magyars to the end. They gave expedient lip service to the new regime but would not make the transition from ruler to ruled. During the same time, the Slovaks joined with the Czechs in 
building the country. Perhaps most of the Slovaks did so because they saw the new state as their country.

\section{THE POLISH MINORITIES: 1919 - 1938}

The re-birth of Poland was very painful. Czechoslovakia started its life with excellent leadership, a cadre of professional occupations, a productive industrial complex, and the best wishes of most of the world. Poland's first days seemed almost friendless. The British never were enthusiastic over a new Poland, the United States was concerned with infringement on Russian rights, and France, the one firm ally, was more interested in power balancing than humanitarianism.

In February, 1919, the new Polish Parliament opened with a major internal division. On the left was Joseph Pilsudski, leader of the Polish forces that fought Tsarist Russia. On the right was Roman Dmowski, leader of a very nationalistic group that supported Polish forces fighting with France against the Central Powers. Pilsudski emerged as the new leader but faced the constant opposition of the Dmowski forces.

While Parliament debated and voted, the question of the eastern boundary of Poland remained undecided. Soviet Russia was moving westward as German forces withdrew. Pilsudski saw a need to move Polish forces into territory he considered to be part of the 
new Poland. The result, a war with Soviet Russia, bears on this study in that the Treaty of Riga, concluding the war on March 18, 1921, set the final eastern boundary of Poland. That boundary decision brought roughly 5,000,000 people into the new Poland, the majority being Ukrainians and White Russians. 41

World War I and the war with Soviet Russia left Poland an exhausted and politically divided country. Poland was also divided socially, for the Poles came from the three partitioned sectors of Poland, where they had led quite different lives. Unity was the first requirement and it was found in Polish nationalism, the same nationalism that was ingrained in the other nationalities of Eastern Europe. It is this very strong Polish nationalism that should be kept in mind as the thesis reviews the fate of the Polish minorities.

\section{The Polish Germans}

In 1921, Poland contained about 1,000,000 Germans out of a total population of about 27,000,000. By 1931, the German total was down to $750,000.42$ Prominent in industry and agriculture, but

${ }^{41}$ See Appendix A for census breakdown. For a summary of this little known but locally very important struggle, see Halecki, op. cit., pp. 283-89. Also see Robert Machray, Poland: 1914-1931, (London: George Allen and Urwin, Ltd., 1932), pp. 182-85, and Joseph Pilsudski, Year 1920, (London: Pilsudski Institute, 1972).

42 The $25 \%$ decline may have been due to emigration, but more likely it was related to the census taking system. It was simply easier to tell the census taker you were a Pole, especially in the antiGerman climate of Poland in the years from 1921 to 1931. 
scattered rather widely over western Poland, German total numbers were small but German problems were very large. To this German minority, the Poles extended their suspicion and an invitation: love us or leave us. Suspecting all Polish-Germans of being primarily loyal to the German fatherland, there was never any serious attempt to bring the German into the Polish government. There apparently was also no serious German desire to join. According to Hugh Seton-Watson, the Germans regarded their Polish residence as only temporary. They were supported in this view by all Berlin governments from Ebert to Hitler. At the same time the Polish authorities held to an equally "provocative attitude. ${ }^{43}$ In this climate of mutual distrust, the Hitler movement was quickly picked up by the Polish-Germans. By 1938, it was estimated that $75 \%$ of the German minority was in full sympathy with the Third Reich. 44

In education, the letter of the Treaty law may have been observed but not the spirit. Emphasis on Polish subjects and use of Polish teachers with a poor mastery of the German language, were among the stream of complaints coming from the Germans. The physical quality of school structures was also a common complaint although it is noted that the number of strictly "German" schools was ${ }^{43}$ Hugh Seton-Wats on, op. cit., p. 279.

${ }^{44} \mathrm{~J}$. C. Hesse, "The Germans in Poland," in the Slavonic Review, op. cit., Vol. 16, p. 95. 
roughly proportionate to the minority population. ${ }^{45}$ From all sides, there was no doubt about the Polish desire to Polonize all areas. This policy reached into the classroom as well as the church and all other channels of cultural life.

The same was true in economics, including agriculture. "Land reform" meant breaking up the large German-held estates and re-issuing them to Polish farmers. In some cases, the Poles terminated land leases on Polish lands that had been granted to Germans by the Prussian government. This was in direct violation of the property-rights section of the Treaty. ${ }^{46}$ As the Poles moved to nationalize certain parts of their industry, German firms seemed to be a particular target. 47 In spite of these trends, 1938 saw the Germans still dominating the industry of the important Lodz area and continuing as the executives and technicians of Upper Silesia. ${ }^{48}$

There were still other factors to consider. The Poles claimed a Polish minority in Germany of about 1,500,000. A Reich policy of Germanization was generally recognized. 49 One of the principal

\section{5} Buell, op. cit., p. 242.

46 Ibid., p. 243.

$47_{\text {Hesse, op. cit., p. } 97 .}$

${ }^{48}$ Buell, op. cit., pp. $246-47$.

${ }^{49}$ See Halecki, op. cit., pp. 257-58, for comments on "Germanization" and "Hakatism," a name applied to German nationalism. See also note 12, Chapter II. 
Polish objections to the Treaty (and acknowledged by the Conference) was that the Poles in Germany were not covered by any guarantee of rights. A related irritant was the continuing action in the League of Nations. In 1926 Germany joined the League. What followed was a steady stream of German complaints over the alleged Polish mistreatment of the German minority. As the Germans complained from their privileged sanctuary, the resentment of the Poles grew. Knowing of the oppression of their relatives in Germany, the Poles directed some of their resentment against the Germans in Poland. The reciprocity and League factors gained new importance in 1934 when the USSR became a League member. Based on German use of the League for minority complaints, Poland could see the USSR doing the same thing on behalf of all the Ukrainians and White Russians in the east. This led to the Polish notice to the League, in the fall of 1934, that Poland was henceforth refusing compliance with all minority provisions of the Treaty until such provisions were extended to all League members. 50

There does not seem to be ary contention that a more benevolent policy toward the German minority would have changed the PolishGerman sympathies with the Third Reich. It is more the thought that the Poles accelerated those sympathies by denying the Polish-Germans any alternatives. 
The Polish-Jews

The dominant theme of post-war Poland was nationalism.

One reads repeatedly of the "Polonizing" programs among German and Ukrainian groups, but not in the Jewish sectors. At the governmental level, the major blame for the very existence of the Minority Treaty was laid on the Jews. The special sections regarding Jewish rights were seen as a public warning of Polish anti-Semitism. A very inflamatory factor was the affection displayed by some Jews for German and Soviet societies, in view of the fact that both Germany. and the USSR were bitter enemies of Poland. The National Democrats, under Dmowski, preached hard-line nationalism and open antiSemitism. On the left, Pilsudski, who was winning both the war and the government, had to recognize the strength of the National Democrats. At times, the Pilsudski government deplored antiSemitic excesses but never took a firm stand. ${ }^{51}$

At the people level, the basic hatred surfaced. Economic competition, religious conflicts, and cultural gaps, were all accented by the Jewish "visibility." The result of all this was the polarizing, not Polonizing; of the two sides. 52 The "alien" nature of the Jews

${ }^{51}$ See Hugh Seton-Watson, op. cit., pp. 288-96, as well as Buell, op. cit., Chapter XI, for documentation of the Jewish-Polish position.

52 "Polarizing" is the author's personal description of situation. 
was accepted by the Poles as an inconvertible fact. This marked a change from pre-war partitioned Poland where Jewish assimilation into Polish life was at least underway to some degree.

Politically, polarizing meant exclusion from any political power. Jewish parties elected deputies to the Polish Diet, but the Jewish deputies had no effective vote. Legislation seemed to follow the anti-Semitic trend. In 1924, the "Language laws" repeated Treaty provisions regarding use of minority languages in legal and civil situations, but excluded the Jews. ${ }^{54}$ The Jewish Community Law of 1927 recognized the Jewish communities and councils, but gave the government the right of supervision, approval of Jewish officials, and even a degree of budget control. ${ }^{55}$ Both of these laws were in direct violation of Article Ten of the Treaty. By 1934, the government officially dispensed with all Treaty restrictions, and by 1936, came the declaration of the head of the Catholic Church: "One does well to prefer his own kind in commercial dealings and to avoid Jewish stores and Jewish stalls in the market, but it is not

53 Heller, op. cit., Chapter VI (183-209) is entitled the "Assimilationists" and treats this situation in depth.

54

Buell, op. cit., pp. 295-96. The explanation was that the Jews were dispersed throughout the country, thus requiring all administrators to learn Yiddish.

${ }^{55}$ Ibid., p. 297. 
permissible to demolish Jewish businesses. ${ }^{56}$ The year 1938 saw the National Democrats calling for complete prohibition of Jewish rights in voting, office holding, and land ownership, with total emigration as the only solution. 57

The economic situation was just as bad. While no laws prevented Jewish business activity, the polarized climate was a massive hurdle. Policies requiring prominent owner identification of business establishments added to the problem, and in 1927, artisan licenses were issued based on examinations in the Polish language only. The Polish objective appears to have been a gradual economic strangulation rather than outright elimination.

There never was any appreciable cultural exchange between the pre-war Jewish and Polish communities, but neither were they completely separate. In the polarized atmosphere of independence, all progress broke down. Contrary to the Treaty, there we re few provisions for Jewish minority schools. ${ }^{58}$ In higher education, there

${ }^{56}$ Ibid., p. 299. This was in a pastoral letter issued during a boycott of Jewish business.

\section{7} Ibid., p. 300. In addition to these Buell citations, the reader is referred to Stephan Horak, Poland and Her National Minorities: 1919-1939, (New York: Vantage Press, Inc. 1961), pp. 111-26, for further detail on the position of the Jews.

${ }^{58}$ Joseph S. Roucek, "Minorities," in Poland, ed., Bernadotte E. Schmidt, (Berkeley: Univ. of California Press, 1947), p. 161. Hereafter cited as Roucek. 
was constant pressure for restrictions on Jewish professional training through quota systems. By 1935, the combination of the Nazi movement and the death of Pilsudski brought renewed activity. The universities were a hotbed of nationalism. The infamous "ghetto-bench" regulation was passed in 1933, requiring Jewish students to use specified seats. By 1936, Jews in higher education were down $40 \%$ from 1923 and in medical schools, down $70 \%$. ${ }^{59}$ The Jewish Sabbath, culturally as well as economically, was a great problem. In the Polish-Catholic state, Sunday was, by law and custom, a.day of rest. In the climate of those times, both the Treaty provision regarding the Sabbath and the weekly observances of the Sabbath added to the total problem.

The special problem presented by the Polish-Jews was their separate existence. The Jews claimed the desire to be left alone. The Poles said to be "left alone" was not their idea of citizenship. Poland, the Poles said, was for Poles. Since there was no possible way for the Jew to be recognized by the Pole as a Pole, there was no place for Polonizing, only polarizing. 60 The Treaty never had a chance.

${ }^{59}$ Roucek, op. cit., p. 162. During this same period, nonJewish enrollment in higher education was up by $50 \%$.

$6^{60}$ The comments regarding Jewish separatism are a summation of extensive reading in the Howe, Epstein, and Heller texts. It is believed to be a proper statement of the problem. 


\section{Polish-Ukrainians}

The Poles were completely opposed to the Minority Treaty. In the case of the Ukrainians, the Poles felt the Treaty did not exist. When the Treaty was signed, the eastern boundary was not determined. It took two more years, a small war with the Ukrainians, a big war with Soviet Russia, and the Treaty of Riga to decide the eastern boundary of Poland. That, according to a Pole, gave him the right to run Galicia and the Volhynia districts as a part of Poland, for the Poles. The Conference of Ambassadors ${ }^{61}$ recognized Polish claims on Galicia and Volhynia in 1923, without any Minority Treaty amendments or references.

Poland's claim on Galicia was not uncontested. In 1920 and again in 1922, conventions of all Ukrainian parties were held in eastern Galicia, proclaiming absolute opposition to Poland and independence for the whole of Ukraine. In September, 1922, Poland passed a law providing for an autonomous government for the Galician provinces with Ukrainian majorities. It was apparently merely an appeasement gesture for its provisions were never carried out. Furthermore, the continued rise of the USSR and the bond between the Soviet Ukraine and eastern Galicia, affected Polish plans. The

${ }^{61}$ Ambassadors of the Allied Powers assigned to final details of the Versailles Treaty. 
Poles saw autonomy for Galicia much as the Czechs saw it for Ruthenia - merely the first step toward losing the land.

So the Polish policy was to Polonize the area. The Polish nationalist took the position that the Ukrainians were fellow-Slavs with a language that was merely a local dialect. Any Ukrainian independence movement, according to the Polish nationalist, was the work of a few individuals and not broadly based among the Ukrainian people. In short, the assimilation into Polish life should be quite natural and brief. Following this line, political policy limited the Ukrainians to representation without authority. The civil service, the military, the local power points, were all heavily Polish before World War I, and now became even more so. Strong action was taken against all things "Ukrainian" including even the Boy Scouts. 62

This policy extended to economics wherever possible. Land reform was always called for, and was used as a form of colonizing. Land was only taken from non-Polish interests and, in the main, parceled out to Poles, with the intent of developing local Polish majorities. Already controlling industry, the Poles moved to tighten their control over everything from the cooperatives to the bureaucracy.

The squeeze in education was part of the policy. In pre-war 62 Buell, op. cit., p. 276. 
years, Galicia had both a Polish and Ukrainian school system, side by side and separate. Under the laws of 1924, the Polish-Ukrainian schools were set up and became the standard. ${ }^{63}$ This produced the common Ukrainian complaint of Polish teachers and Polish bias. The bias was apparent in the lack of Ukrainian university students and in conversion to all-Polish classes at the University of Lwów.

The program of the National Democrats declared, "We shall win the Slavic minority through assimilation of the masses and fight against the hostile individual, "64 and fight they did. As the assimilation pressure increased, resistance broke out. The year 1930 saw major Ukrainian terrorist activity against Pclish policies, ${ }^{65}$ followed by Polish "pacification" in which whole villages were punished for one terrorist act. Reacting to this violence, Poland eased off the assimilation policy, encouraging more political representation, more Ukrainian teachers, and more recognition of things Ukrainian. Through 1938, however, the Ukrainian continued to protest against Polish dominance in all phases of his life. The special Ukrainian

63 Horak, op. cit., pp. 143-44. 64 Buell, op. cit., p. 276.

${ }^{65}$ Machray, op. cit., pp. 406-08, and Hugh Seton-Watson op. cit., pp. 334-35. These authors detail the activity of the Ukrainian Military Organization and various extremist groups in acts of sabotage and terrorism against Polish administrators and Polish property, as well as the Polish "pacification" reaction. 
problem faced by the Poles was the need to turn the Ukrainian local majority into a contributing part of the Polish state. The directed official policy of assimilation produced violence and strong Ukrainian unity: It did not produce Polish citizens.

The tragedy of the Polish minority experience must lie in the waste of human resources. If Poland needed anything, Poland needed teachers, doctors, engineers, lawyers, production managers, and designers. Poland had them but it could not see them because they were Germans and Jews and Ukrainians. If the Pole could have seen a.doctor, not a Jew; could have seen an engineer, not a German; could have seen a teacher, not a Ukrainian; they could have built Poland by day and gone home to their traditional cultures by night and just maybe, met in the park on a summer evening. Time was not their problem. Leadership and vision might have shown the way. More likely, the chaotic-birth, the Great Depression, the German bugles, and the Soviet shadow made daily adverse reaction to each other the only choice. 


\section{CHAPTER V}

\section{CONCLUSIONS}

The men of the Paris Peace Conference tried to produce a new map of Eastern Europe that followed the principle of selfdetermination and the lines of nationality. Looking back over the Conference action, one can be critical of the absence of any mention of minority obligation. One can bemoan the inability of the Conference to require all countries to recognize certain basic minority rights. One can also cite numerous examples where the principle of self-determination was abandoned or compromised. On the other hand, there were very positive accomplishments - the Poles and Czechs and Slovaks and the Southern Slavs all had their new states, while Hungary was reduced to Hungarians and Austria to Austrian-Germans. The rights of the resulting minorities were proclaimed by the Conference and spelled out in the Minority Treaties. Giving due consideration to the situations they faced, the conferees accomplished their self-assigned task.

While the boundary task was accomplished, the hoped-for result - the unity of the population of each new state - was a failure. The early post World War II years saw only the separation of the 
rulers and the ruled. Throughout Eastern Europe the Germans were sent back to Germany and the Jews either died or emigrated. The Ukrainians and White Russians of Poland were annexed by the USSR, as were the Ruthenians of Czechoslovakia. Only the Magyars of Czechoslovakia remained in Slovakia, where they are today, still Magyars.

The Minority Treaties did not solve the problem of the national minorities nor did the treaties provide any formula that has since led to any solution. The problem - the reconciliation of the interests of the rulers and the ruled - remains unsolved today. If one accepts the desirability of a world that includes "states of nationalities" then the various "sclutions" since 1945 have been admissions of defeat, or, resignations to a situation, not solutions. How have the interests of the rulers and the ruled been resolved since 1945? There have been few, if any, examples of true reconciliation. There has been only separation in the form of new national states, or mass re-settlement of populations, or extermination. Many of the unresolved situations have either erupted in bitter warfare (Northern Ireland and Israel) or show signs of serious political conflict (Quebec).

The hope for "states of nationalities" in which diverse populations live together in peace and equality, must rely heavily: on an improved understanding of the interests of both sides, the 
rulers as well as the ruled. To that end, the thesis examination of the Minority Treaties, the Conference that created the treaties, and Czechoslovakian and Polish minorities that resulted from the treaty events, has illuminated certain characteristics of human behavior and human relations. These characteristics are as applicable to the world today as they were to the Czechs and Poles in the years following World War I.

Foremost among these characteristics is the understanding that nationality is a perception, not subject to any exact definition. "I am what I am," is one way to put it. R. W. Seton-Watson put it a more complete way by contending, "A man's nationality ... is something compounded of race, language, tradition, and innermost feeling . . something physiological and sacred. " $"$ Being a perception and containing elements of feeling and affection, one's nationality can therefore be changed. While the Slovak remained a Slovak in spite of the long Magyar rule, the Slovak that emigrated to America became an American-Slovak within one generation. In America, his primary identification rapidly shifted to the state that offered, in his opinion, the best chance to attain his aspirations. The nationality change of so many of the American immigrants could be repeated in many of today's minority situations. That

${ }^{1}$. W. Seton-Watson, "The Question of Minorities" in Slavic Review, op. cit., Vol. 14, p. 80. 
possibility rests with the ruling majority. It was, and still is, the task of the ruling majority to create a climate of opportunity that matches the aspirations of the ruled minorities. Such a climate could make a major difference in Northern Ireland, in Israel, in Zaire or Angola. It could have made a difference in Eastern Europe, but the rulers were too busy ruling to create such a climate.

The second revealed characteristic has to do with assimilation and the factor of acceptance. Assimilation means, "to make similar" or "to absorb into the cultural tradition of a population." Assimilation was the common policy of those years, and, as a policy of a state, it proved to be counter-productive. The Magyars could not make Magyars out of Slovaks or Ruthenians any more than the Germans could make Germans out of Poles, or the Poles could make Poles out of Ukrainians. True, the rulers could get the votes and the services of the ruled minority but the directed assimilation also produced or encouraged terrorists, Pan-Slavic and Pan-German movements, and perpetuation of nationality.

The failure of directed assimilation is related to the factor of acceptance. In the years from 1919 to 1938, there never was an exhibited concern over the acceptance of directives. Fresh out of an age of autocracy, "acceptance" simply meant compliance. Related to management affairs - and running a "state of nationalities". is surely management - the acceptance of decisions, decrees, or 
policies, means agreement with the basic objectives. In all matters where the actions or behavior of the recipient of the directive is vital to the success of the directive, the acceptance factor is critical. At the local level, and often at the leadership level, neither Czechoslovakia nor Poland had a sufficient concern for the development of this all-important factor.

The re is no doubt that the reconciliation of the interests of the majority and minority must involve some degree of assimilation. Any alternative to separation such as federation or regional autonomy or simply equality of citizenship, requires some level of melding of the interests and cultures of the two parties. Assimilation, therefore, can well be a long-term objective, requiring the presence of the factor of acceptance - but assimilation, via proclaimed policy, is doomed to fail.

The third characteristic revealed by this brief study is that tolerance and legal freedoms do not equate with equality. The Minority Treaties set up a legal framework of freedom, specified a climate of tolerance and repeatedly used the terms "equal" and "equality." Yet, it is interesting to note that the definition of "equal" specifies "like in quality, nature, or status," while the definition of "tole rance" refers to sympathy, indulgence, and allowing, but does not mention equality.

Equality must be more of a perceived attitude than a definable 
state. Austria granted tolerance and freedoms to the Czechs, but not equality and the Czechs replied in kind. On today's scene, no one can question the religious tolerance and legal freedom extended by Canada to the French-Canadians. Despite this framework of freedom, the separatist movement in Quebec grows as the FrenchCanadian seeks true equality, not tolerance. In the view of the minority, equality is equated more with perceived opportunity or attainment of aspirations than with legality. If an individual member of a minority sees the ruling majority as a block to attainment of his aspirations, then no degree of tolerance or legal freedoms will do away with that perception.

Time is a prominent factor in most situations. It bears on the basic decision and on the developing solution. A common characteristic of human behavior is to let time alone provide a solution. These minority situations, however, carry the message that the passage of decades, generations, or even centuries, do not change basic nationality perceptions. It is true that time may give some as similative or healing factor a chance to diffuse and take effect, but time, by itself, will do nothing. This study provides a very real reminder that "leaving them alone" will not make Is raeli citizens out of Arabs, or good neighbors out of the Catholic Irish of Northern Ireland, or Spaniards out of Basques, any more than it made Magyars out of Slovaks or Germans out of Poles. If there is a minority problem 
confronting the state, then the state must address it today. Time will only bequeath the problem to the next generation, in full flower and fury.

These four illuminated characteristics - the perception of nationality, the failure of directed assimilation and need for acceptance, the gap between equality and tolerance, and the role played by time - have been viewed and reviewed many times before. If these characteristics contained, within themselves, the principal ingredients needed for a reconciliation of the interests of the rulers and the ruled, then the world should have seen many examples of such reconciliations. Unfortunately, the reverse is true. There have been very few reconciliations since 1945 and minority group demands are proliferating. There must, therefore, be other human characteristics to consider.

On this point it is possible that the catalytic characteristic is the rather uncommon one of humanitarianism, defined as, "concern for human welfare." All evidence suggests that both Thomas Masaryk and Joseph Pilsudski wère humanitarian leaders, but that leader level was not the only place where the humanitarians were needed. The exhibiting of concern for human welfare was needed on the street, in the factory, over the back fence, as well as in the Parliaments. With such a concern, the Polish employee might have seen the job applicant as a talented textile worker, not a Jew. 
In the same manner, humanitarianism might lead the English employer in Uilster to view the Irish Catholic applicant as a qualified dock worker, or the Israeli employer to see the Arab as a doctor. Humanitarianism, as a single factor, will not reconcile the interests of the rulers and the ruled. The absence of humanitarianism, however, is a block to any hopes of such reconciliation, just as the same absence from the local scenes in Czechoslovakia and Poland turned the Minority Treaties into useless pieces of paper.

The objective of this thesis is to promote, through a review of some past minority problems, the listening to, and evaluation of, the cries of today's minorities. Among the more audible cries are those of Palestine, Northern Ireland, and the African group. Joining the chorus are the Basques and Croats, the South Moluccans and Azorians. The Bretons, Welsh, and Scots add to a still incomplete list. It is a basic premise of the thesis that there is a desirable place in the world for "states of nationalities" as well as national states. If one accepts that premise, then one must accept the need for solutions of the minority problems that encompass reconciliation as well as separation. The the sis can contribute to understanding and promote listening and evaluation, but the thesis cannot attempt solutions. The enormous complexity and the ever-lasting presence of the problem of the national minority was well stated by President Edward Bene $\breve{s}$ in his review of Czechoslovakia's achievements and 
failures in the years up to 1938 :

We have had, and still have, one problem; a problem fraught with difficulty, now as for centuries past on our territory, a problem which calls for ever new forms of solution the problem of the nationalities. 2

${ }^{2}$ HCR, op. cit., p. 187. 


\section{A SELECTED BIBLIOGRAPHY}

Almost every publication relating to the subject countries, or to the Paris Peace Conference, or to European nationalism, contains some material relevant to the thesis. Out of this vast supply, the following basic works, texts, monographs, memoirs, special articles and documents have been selected. These selections, all from the libraries of the Portland metropolitan area, cover the countries and minorities included in this thesis, the general scene in Eastern Europe and Paris in 1919, and the special subjects of the Peace Conference, nationalism, and Judaism.

I. PRIMARY SOURCES (Government documents and personal memoirs)

Bonsal, Stephan. Suitors and Supplicants, New York: Prentice Hall, 1946.

DeAzcarate, P. League of Nations and National Minorities, Washington D.C.: Carnegie Endowment for International Peace, 1945.

Dillon, E. J. The Inside Story of the Peace Conference, New York: Harper and Bros., 1920.

Foreign Relations of the United States: The Paris Peace Conference, 1919, 13 Vols., Washington, D.C., U. S. Government Printing Office, 1947. 
Goodhart, Arthur I. Poland and the Minority Races, London: George Allen and Urwin, Ltd., 1920.

House, Edward M.; Seymour, Charles, ed. What Really Happened at Paris, New York: Charles Scribner's Sons, 1921.

Lansing, Robert. The Peace Negotiations, Cambridge: Riverside Press, 1921.

Lloyd George, David. Memoirs of the Peace Conference, 2 Vols., New York: Howard Fertig, 1972.

Masaryk, Thomas. The Making of a State, New York: Frederick A. Stokes, Co., 1927.

Miller, David Hunter. My Diary at the Conference of Paris, New York: Appeal Printing Co., 1924.

Pilsudski, Joseph. Year 1920, London: Pilsudski Institute of London, 1972.

Temperley, H.W. V. History of the Peace Conference of Paris, 6 Vol., London: Institute of International Affairs, 1921.

The Treaty of Versailles. Washington, D.C., United States Government Printing Office, 1947.

II. SECONDARY SOURCES

A. Monographic Selections

Allen, William E. D. The Ukraine, Cambridge: Cambridge Univ. Press, 1940.

Black, C.E. Challenge in Eastern Europe, New Brunswick: Rutgers Univ. Press, 1954.

Bruegel, J. S. "The Germans in Pre-War Czechoslovakia," A History of the Czechoslovak Republic: 1918-1948, Ed. V.S. Mamatey and R. Luza, Princeton: Princeton Univ. Press, 1973. 
Buell, Raymond Leslie. Poland: Key to Europe, 3rd ed., New York: Alfred A. Knopf, 1939.

The Cambridge History of Poland, ed. W. F. Reddoway, J. H. Penson, O. Halecki, R. Dyboski, Cambridge: Cambridge Univ. Press, 1951.

Cobban, Alfred. National Self-Determination, Chicago: Univ. of Chicago Press, 1951.

Doroshenko, D. History of the Ukraine, Edmonton: Institute Press, 1939.

Epstein, Isadore. Judaism, London: Penguin Books, Ltd., 1959.

Halecki, Oscar. Borderlands of Western Civilization, New York: The Ronald Press Company, 1952.

Hayes, Carlton J. H. Nationalism: A Religion, New York: The Macmillan Company, 1960.

Heller, Celia S. On the Edge of Destruction: Jews of Poland Between the Wars, New York: Columbia Univ. Press, 1977.

Horak, Stephan. Poland and Her National Minorities: 1919-1939, New York: Vantage Press, Inc., 1961.

Howe, Irving. World of Our Fathers, New York: Harcourt, Brace, Jovanovich, 1976.

Hrushevsky, Michael. A History of the Ukraine, New Haven: Yale Univ. Press, 1941.

Kann, Robert. The Multinational Empire, 2 Vol., New York: Columbia Press, 1950.

Kaplan, Herbert H. The First Partition of Poland, New York: Columbia Univ. Press, 1962.

Kerner, Robert J. Bohemia in the Eighteenth Century, Orno: Academic International, 1969.

Kerner, Robert J., ed. Czechoslovakia, Berkeley: Univ. of Calif. Press, 1919. 
King, Robert R. Minorities Under Communism, Cambridge: Harvard Univ. Press, 1973.

Kohn, Hans. Nationalism: Its Meaning and History, New York:

Van Nostrand Reinhold Company, 1965.

Komarnicki, Titus. Rebirth of the Polish Republic, London:

William Heineman, Ltd., 1957.

Kubijovyc, Volodymyr. Ukraine: A Concise Encyclopedia, 2 Vol.,

Toronto: Univ. of Toronto Press, 1963.

Lord, Robert H. The Second Partition of Poland, Cambridge: Harvard Univ. Press, 1915.

Lyons, Thomas; Rozwenc, Edwin C. Realism and Idealism in Wilson's Peace Program, Boston: D. C. Heath and Company, 1965.

Macartney, C. A.; Palmer, A. W. Independent Eastern Europe: A History, London: Macmilian and Co., Ltd., 1962.

Macartney, C. A. Hungary and Her Successors, London: Oxford Univ. Press, 1937.

Machray, Robert. Poland: 1914-1931, London: George Allen and Urwin, Ltd., 1932.

Mamatey, Victor S. ; Luza, Radomia, Ed. A History of the Czechoslovak Republic: 1918-1948, Princeton: Princeton Univ. Press, 1973.

Margolin, Arnold D. Russia, The Ukraine, and America, New York: Columbia Univ. Press, 1946.

Meyer, Henry Cord. Mitteleuropa In German Thoughts and Action, The Hague: Martinus Nijhoff, 1955.

Palmer, Alan. The Lands Between, London: Weidenfeld and Nicolson, 1970.

Portal, Roger. The Slavs, Weidenfeld and Nicolson, 1969.

Pounds, Norman. Eastern Europe, Chicago: Aldine Publishing Company, 1969. 
Roberts, Henry L. Eastern Europe: Politics, Revolution, and Diplomacy, New York: Alfred A. Knopf, 1970.

Rothschild, Joseph. East Central Europe Between the Two World Wars, Seattle: Univ. of Washington Press, 1974.

Schmidt, Bernadotte E., ed. Poland, Berkeley: Univ. of California Press, 1947.

Schreiber, Hermann. Teuton and Slav, New York: Alfred A. Knopf Co., 1965.

Seton-Watson, Hugh. Eastern Europe Between the Wars: 1918-1941, 3rd ed., Hamden: Archon Books, 1962.

Seton-Watson, R. W. Racial Problems in Hungary, New York: Howard Fertig, 1972.

Seton-Watson, Robert W. A History of the Czechs and Slovaks, Hamden: Archon Books, 1965.

Seton-Watson, Robert W. Masaryk in England, Cambridge: Cambridge Univ. Press, 1943.

Shafer, Boyd C. Faces of Nationalism, New York: Harcourt, Brace, Jovanovich, Inc., 1972.

Thompson, John. Russia, Bolshevism, and the Versailles Peace, Princeton: Princeton Univ. Press, 1966.

Wallace, William V. Czechoslovakia, Boulder: Westview Press, 1976.

Wyandycz, Piotr S. The Lands of Partitional Poland: 1795-1918, Seattle: Univ. of Washington Press, 1974.

Wanklyn, Harriet. Czechoslovakia, London: George Phillip and Son, Ltd., 1954.

Wiskemann, Elizabeth. Czechs and Germans, London: Oxford Univ. Press, 1938. 


\section{B. Periodical Selections}

Berlin, Isaiah. "The Bent Twig: A Note on Nationalism," Foreign Affairs, 51 (1972), 11-30.

Birnbaum, S. A. "The Jewries of Eastern Europe," Slavonic Review, 29 (1951), 420-444.

Bromke, Adam. "Nationalism and Communism in Poland," Foreign Affairs, 40 (1962), 635-643.

Broz, Ales. "Minority Rights in the Czechoslovak State," Foreign Affairs, 6 (1927), 158-160.

Doroshenko, D. "The Ukrainian National Movement," Slavonic Review, 16 (1938), 654-666.

Gasiorowski, Z.J. "Joseph Pilsudski: In the Light of American Reports," Slavonic Review, 49 (1971), 425-436.

Hesse, J. C. "The Germans in Poland," Slavonic Review, 16 (1937), 93-101.

Kiss, Desider. "The Jews of Eastern Europe," Foreign Affairs, 15 (1936), 330-339.

Manning, C. A. "Language As a Factor in Polish Nationalism," Slavonic Review, 13 (1934), 155-176.

Miller, David Hunter. "Nationality and Other Problems Discussed at The Hague," Foreign Affairs, 8 (1929), 632-640.

Ripka, H. "Czechoslovakia's Attitude to Germany and Hungary," Slavonic Review, 23 (1945), 47-54.

Rose, W. J. "The Poles in Germany," Slavonic Review, 15 (1936), 165-176. 
APPENDIX A

POLAND: RACIAL AND RELIGIOUS STATISTICS*

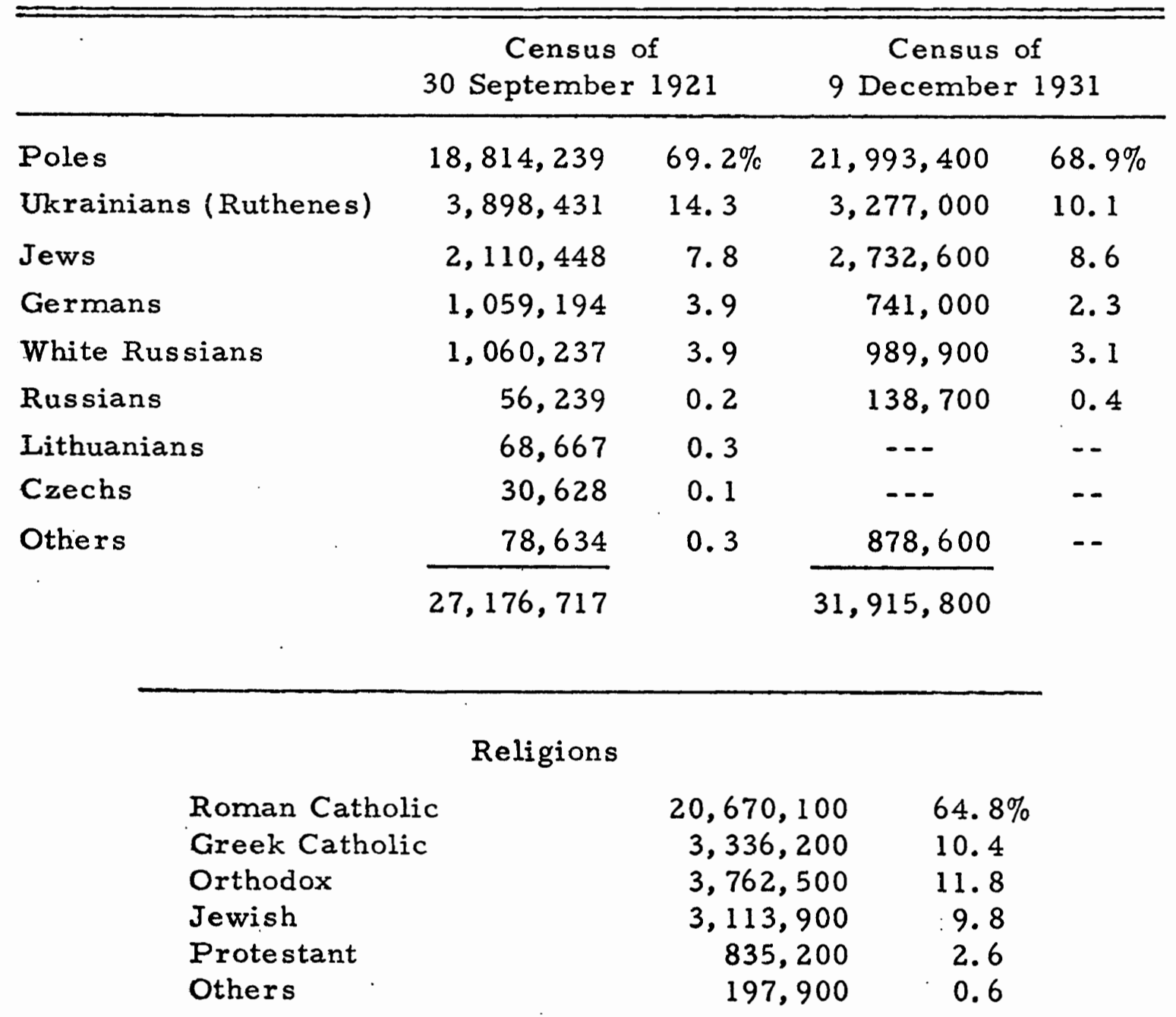

* Hugh Seton-Watson, Eastern Europe Between the Wars: 1918-1941, 3rd ed. : (Hamden: A rchon Books, 1962), p. 414. 
APPENDIX B

CZECHOSLAVAKIA: RACIAL AND RELIGIOUS STATISTICS*

\begin{tabular}{|c|c|c|c|c|}
\hline \multirow[b]{2}{*}{ Czechoslovaks } & \multicolumn{2}{|c|}{$\begin{array}{c}\text { Census of } \\
15 \text { February } 1921\end{array}$} & \multicolumn{2}{|c|}{$\begin{array}{c}\text { Census of } \\
1 \text { December } 1931\end{array}$} \\
\hline & $8,760,937$ & $65.5 \%$ & $9,668,770$ & $66.9 \%$ \\
\hline Germans & $3,123,568$ & 23.4 & $3,231,688$ & 22.3 \\
\hline Magyars & 745,431 & 5.6 & 691,923 & 4.7 \\
\hline Ruthenes (Ukainian & 461,849 & 3.5 & 549,169 & 5.7 \\
\hline Poles & 75,853 & 0.5 & 81,737 & 0.5 \\
\hline Jews & 180,855 & 1.3 & 186,642 & 1.29 \\
\hline Roumanians & 13,974 & 0.1 & 13,044 & 0.09 \\
\hline Gypsies & $-\cdots$ & -- & 52,209 & 0.2 \\
\hline Others & -- & $13,374,364$ & $14,729,536$ & - \\
\hline \multicolumn{5}{|c|}{ Religions } \\
\hline Roman Catholic & $10,831,096$ & Orthodox & \multicolumn{2}{|c|}{145,598} \\
\hline $\begin{array}{l}\text { Greek and Armen- } \\
\text { ian Catholics }\end{array}$ & 584,041 & Old Catholic & $\begin{array}{r}356, \\
22,\end{array}$ & \\
\hline Protestant & $1,129,758$ & \multicolumn{2}{|c|}{ 'Konfessionslos' } & 854,638 \\
\hline $\begin{array}{l}\text { Czechoslovak } \\
\text { Church }\end{array}$ & 793,385 & Others & & \\
\hline
\end{tabular}

*Hugh Seton-Watson, Eastern Europe Between the Wars: 1918-1941, 3rd ed., (Hamden: Archon Books, 1962), p. 414. 


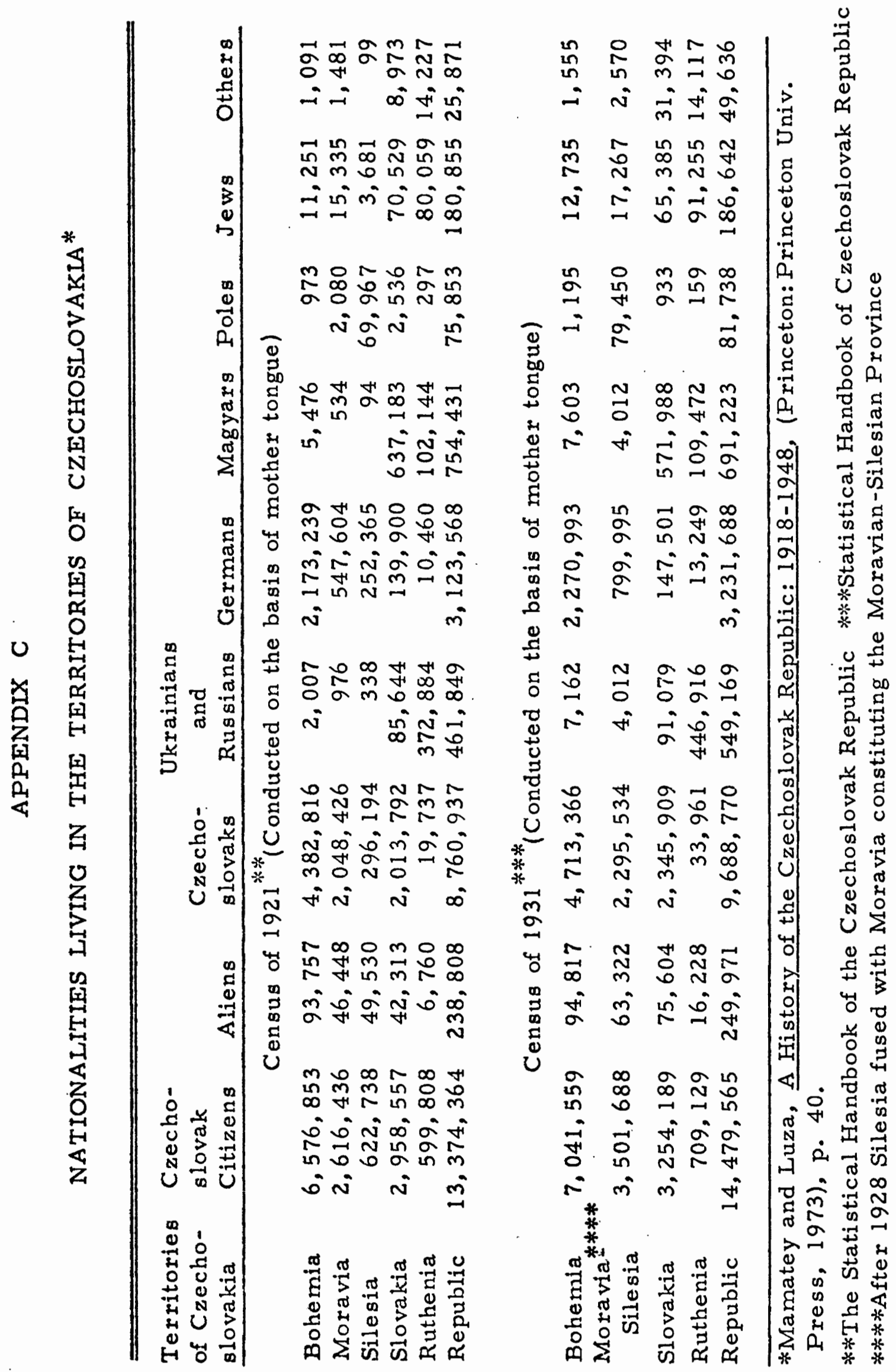




\section{APPENDIX D}

\section{WOODROW WILSON'S FOURTEEN POINT PLAN FOR PEACE*}

The program of the world's peace, therefore, is our program; and that program, the only possible program, as we see it, is this:

I. Open covenants of peace, openly arrived at, after which there shall be no private international understandings of any kind but diplomacy shall proceed always frankly and in the public view.

II. Absolute freedom of navigation upon the seas, outside territorial waters, alike in peace and in war, except as the seas may be closed in whole or in part by international action for the enforcement of international covenants.

III. The removal, so far as possible, of all economic barriers and the establishment of an equality of trade conditions among all the nations consenting to the peace and associating themselves for its maintenance.

IV. Adequate guarantees given and taken that national armaments will be reduced to the lowest point consistent with domestic safety.

* From Wilson's address delivered at a Joint Session of Congress on January 18, 1918. See Robert Lansing, The Peace Negotiations, (Cambridge: Riverside Press, 1921), pp. 314-16. 
V. A free, open-minded, and absolutely impartial adjustment of all colonial claims, based upon a strict observance of the principle that in determining all such questions of sovereignty the interests of the populations concerned must have equal weight with the equitable claims of the government whose title is to be determined.

VI. The evacuation of all Russian territory and such a settlement of all questions affecting Russia as will secure the best and freest cooperation of the other nations of the world in obtaining for her an unhampered and unembarrassed opportunity for the independent determination of her own political development and national policy and assure her of a sincere welcome into the society of free nations under institutions of her own choosing; and, more than a welcome, assistance also of every kind that she may need and may herself desire. The treatment accorded Russia by her sister nations in the months to come will be the acid test of their good-will, of their comprehension of her needs as distinguished from their own interests, and of their intelligent and unselfish sympathy.

VII. Belgium, the whole world will agree, must be evacuated and restored, without any attempt to limit the sovereignty which she enjoys in common with all other free nations. No other single act will serve as this will serve to restore confidence among the nations in the laws which they have themselves set and determined for the government of their relations with one another. Without this bealing 
act the whole structure and validity of international law is forever impaired.

VIII. All French territory should be freed and the invaded portions restored, and the wrong done to France by Prussia in 1871 in the matter of Alsace-Lorraine, which has unsettled the peace of the world for nearly fifty years, should be righted, in order that peace may once more be made secure in the interest of all.

IX. A readjustment of the frontiers of Italy should be effected along clearly recognizable lines of nationality.

X. The peoples of Austria-Hungary, whose place arnong the nations we wish to see safeguarded and assured, should be accorded the freest opportunity of autonomous development.

XI. Rumania, Servia, and Montenegro should be evacuated; occupied territories restored; Servia accorded free and secure access to the sea; and the relations of the several Balkan states to one another determined by friendly counsel along historically established lines of allegiance and nationality; and international guarantees of the political and economic independence and territorial integrity of the several Balkan states should be entered into.

XII. The Turkish portions of the present Ottoman Empire should be assured a secure sovereignty, but the other nationalities which are now under Turkish rule should be assured an undoubted security of life and an absolutely unmolested opportunity of autonomous develop- 
ment, and the Dardanelles should be permanently opened as a free passage to the ships and commerce of all nations under international guarantees.

XIII. An independent Polish state should be erected which should include the territories inhabited by indisputably Polish populations, which should be assured a free and secure access to the sea, and whose political and economic independence and territorial integrity should be guaranteed by international covenant.

XIV. A general association of nations must be formed under specific covenants for the purpose of affording mutual guarantees of political independence and territorial integrity to great and small states alike. 


\title{
APPENDIX E
}

\section{MINORITY TREATY BETWEEN POLAND AND THE ALIIED AND PRINCIPAL POWERS*}

\author{
CHAPTER I
}

\section{ARTICLE I}

Poland undertakes that the stipulations contained in Articles 2 to 8 of this Chapter shall be recognized as fundamental laws, and that no law, regulation or official action shall conflict or interfere with these stipulations, nor shall any law, regulation or official action prevail over them.

\section{ARTICLE 2}

Poland undertakes to assure full and complete protection of life and liberty to all inhabitants of Poland without distinction of birth, nationality, language, race or religion.

All inhabitants of Poland shall be entitled to the free exercise, whether public or private, or any creed, religion or belief, whose

*Appendix includes only Chapter I of the treaty. Chapter II deals only with diplomatic and commercial provisions not relevant to this thesis. See H.W.V. Temperley, ed., A History of the Peace Conference of Paris, 6 Vol., (London: Institute of International Affairs, 1921), Vol. 5, pp. 798-801. 
practices are not inconsistent with public order or public morals.

\section{ARTICLE 3}

Poland admits and declares to be Polish nationals ipso facto and without the requirement of any formality German, Austrian, Hungarian or Russian nationals habitually resident at the date of the coming into force of the present Treaty in territory which is or may be recognized as forming part of Poland, but subject to any provisions in the Treaties of Peace with Germany or Austria respectively relating to persons who became resident in such texritory after a specified date.

Nevertheless, the persons referred to above who are over eighteen years of age will be entitled under the conditions contained in the said Treaties to opt for any other nationality which may be open to them. Option by a husband will cover his wife and option by parents will cover their children under eighteen years of age.

Persons who have exercised the above right to opt must, except where it is otherwise provided in the Treaty of Peace with Germany, transfer within the succeeding twelve months their place of residence to the State for which they have opted. They will be entitled to retain their immovable property in Polish territory. They may carry with them their movable property of every description. No export duties may be imposed upon them in connection with the re- 
moval of such property.

\section{ARTICLE 4}

Poland admits and declares to be Polish nationals ipso facto and without the requirement of any formality persons of German, Austrian, Hungarian or Russian nationality who were born in the said territory of parents habitually resident there, even if at the date of the coming into force of the present Treaty they are not themselvies habitually resident there.

Nevertheless, within two years after the coming into force of the present Treaty, these persons may make a declaration before the competent Polish authorities in the country in which they are resident, stating that they abandon Polish nationality, and they will then cease to be considered as Polish nationals. In this connection a declaration by a husband will cover his wife, and a declaration by parents will cover their children under eighteen years of age.

\section{ARTICLE 5}

Poland undertakes to put no hindrance in the way of the exercise of the right which the persons concerned have, under the Treaties concluded or to be concluded by the Allied and Associated Powers with Germany, Austria, Hungary or Russia, to choose whether or not they will acquire Polish nationality. 


\section{ARTICLE 6}

All persons born in Polish territory who are not born nationals of another State shall ipso facto become Polish nationals.

\section{ARTICLE 7}

All Polish nationals shall be equal before the law and shall enjoy the same civil and political rights without distinction as to race, language or religion.

Differences of religion, creed or confession shall not prejudice any Polish national in matters relating to the enjoyment of civil or political rights, as for instance admission to public employments, functions and honours, or the exercise of professions and industries.

No restriction shall be imposed on the free use by any Polish national of any language in private intercourse, in commerce, in religion, in the press or in publications of any kind, or at public meetings.

Notwithstanding any establishment by the Polish Government of an official language, adequate facilities shall be given to Polish nationals of non-Polish speech for the use of their language, either orally or in writing, before the courts. 


\section{ARTICLE 8}

Polish nationals who belong to racial, religious or linguistic minorities shall enjoy the same treatment and security in law and in fact as the other Polish nationals. In particular they shall have an equal right to establish, manage and control at their own expense charitable, religious and social institutions, schools and other educational establishments, with the right to use their own language and to exercise their religion freely therein.

\section{ARTICLE 9}

Poland will provide in the public educational system in towns and districts in which a considerable proportion of Polish nationals of other than Polish speech are residents adequate facilities for ensuring that in the primary schools the instruction shall be given to the children of such Polish nationals through the medium of their own language. This provision shall not prevent the Polish Government from making the teaching of the Polish language obligatory in the said schools.

In towns and districts where there is a considerable proportion of Polish nationals belonging to racial, religious or linguistic minorities, these minorities shall be assured an equitable share in the enjoyment and application of the sums which may be provided 
out of public funds under the State, municipal or other budget, for educational, religious or charitable pruposes.

The provisions of this Article shall apply to Polish citizens of German speech only in that part of Poland which was German territory on August 1, 1914.

\section{ARTICLE 10}

Educational Committees appointed locally by the Jewish communities of Poland will, subject to the general control of the State, provide for the distribution of the proportional share of public funds allocated to Jewish schools in accordance with Article 9, and for the organization and management of these schools.

The provisions of Article 9 concerning the use of languages in schools shall apply to these schools.

\section{ARTICLE 11}

Jews shall not be compelled to perform any act which constitutes a violation of their Sabbath, nor shall they be placed under any disability by reason of their refusal to attend courts of law or to perform any legal business on their Sabbath. This provision however shall not exempt Jews from such obligations as shall be imposed upon all other Polish citizens for the necessary purposes of military service, national defence or the preservation of public order. 
Poland declares her intention to refrain from ordering or permitting elections, whether general or local, to be held on a Saturday, nor will registration for electoral or other pruposes be compelled to be performed on a Saturday.

\section{ARTICLE 12}

Poland agrees that the stipulations in the foregoing Articles, so far as they affect persons belonging to racial, religious or linguistic minorities, constitute obligations of international concern and shall be placed under the guarantee of the League of Nations. They shall not be modified without the assent of a majority of the Council of the League of Nations. The United States, the British Empire, France, Italy and Japan hereby agree not to withhold their assent from any modification in these Articles which is in due form assented to by a majority of the Council of the League of Nations.

Poland agrees that any Member of the Council of the League of Nations shall have the right to bring to the attention of the Council any infraction, or any danger of infraction, of any of the se obligations, and that the Council may thereupon take such action and give such direction as it may deem proper and effective in the circumstances. Poland further agrees that any difference of opinion as to questions of law or fact arising out of the se Articles between the Polish Government and any one of the Principal Allied and Associated 
Powers or any other Power, a Member of the Council of the League of Nations, shall be held to be a dispute of an international character under Article 14 of the Covenant of the League of Nations. The Polish Government hereby consents that any such dispute shall, if the other party thereto demands, be referred to the Permanent Court of International Justice. The decision of the Permanent Court shall be final and shall have the same force and effect as an award under Article 13 of the Covenant. 


\section{APPENDIX $F$}

\section{MINORITY TREATY BETWEEN CZECHOSLOVAKIA AND THE ALLIED PRINCIPAL POWERS*}

\section{CHAPTER I}

\section{ARTICLE 1}

Czecho-Slovakia undertakes that the stipulations contained in Articles 2 to 8 of this Chapter shall be recognized as fundamental laws and that no law, regulation or official action shall conflict or interfere with the se stipulations, nor shall any law, regulation or official action prevail over them.

\section{ARTICLE 2}

Czecho-Slovakia undertakes to assure full and complete protection of life and liberty to all inhabitants of Czecho-Slovakia without distinction of birth, nationality, language, race or religion.

All inhabitants of Czecho-Slovakia shall be entitled to the free exercise, whether public or private, of any creed, religion or

\footnotetext{
* Appendix includes only Chapters I and II of the treaty. Chapter III deals only with diplomatic and commercial provisions not relevant to this thesis. See H.W.V. Temperley, ed., A History of the Peace Conference of Paris, 6 Vol., (London: Institute of International Affairs, 1921), Vol. 5, pp. 811-815.
} 
belief, whose practices are not inconsistent with public order or public morals.

\section{ARTICLE 3}

Subject to the special provisions of the Treaties mentioned below, Czecho-Slovakia admits and declares to be Czecho-Slovak nationals ipso facto and without the requirement of any formality German, Austrian or Hungarian nationals habitually resident or possessing rights of citizenship (pertinenza, Heimatsrecht) as the case may be at the date of the coming into force of the present Treaty in territory which is or may be recognized as forming part of CzechoSlovakia under the Treaties with Germany, Austria or Hungary respectively, or under any Treaties which may be concluded for the purpose of completing the present settlement:

Nevertheless, the persons referred to above who are over eighteen years of age will be entitled under the conditions contained in the said Treaties to opt for any other nationality which may be open to them. Option by a husband will cover his wife and option by parents will cover their children under eighteen years of age.

Persons who have exercised the above right to opt must within the succeeding twelve months transfer their place of residence to the State for which they have opted. They will be entitled to retain their immovable property in Czecho-Slovak territory. They may 
carry with them their movable property of every description. No export duties may be imposed upon them in connection with the removal of such property.

\section{ARTICLE 4}

Czecho-Slovakia admits and declares to be Czecho-Slovak nationals ipso facto and without the requirement of any formality persons of German, Austrian or Hungarian nationality who were born in the territory referred to above of parents habitually resident or possessing rights of citizenship (pertinenza, Heimatsrecht) as the case may be there, even if at the date of the coming into force of the present Treaty they are not themselves habitually resident or did not possess rights of citizenship there.

Nevertheless, within two years after the coming into force of the present Treaty, these persons may make a declaration before the competent Czecho-Slovak authorities in the country in which they are resident, stating that they abandon Czecho-Slovak nationality, and they will then cease to be considered as Czecho-Slovak nationals. In this connection a declaration by a husband will cover his wife, and a declaration by parents will cover their children under eighteen years of age. 


\section{ARTICLE 5}

Czecho-Slovakia undertakes to put no hindrance in the way of the exercise of the right which the persons concerned have under the Treaties concluded or to be concluded by the Allied and Associated Powers with Germany, Austria or Hungary to choose whether or not they will acquire Czecho-Slovak nationality.

\section{ARTICLE 6}

All persons born in Czecho-Slovak territory who are not born nationals of another State shall ipso facto become CzechoSlovak nationals.

\section{ARTICLE 7}

All Czecho-Slovak nationals shall be equal before the law and shall enjoy the same civil and political rights without distinction as to race, language or religion.

Differences of religion, creed or confession shall not prejudice any Czecho-Slovak national in matters relating to the enjoyment of civil or political rights, as for instance admission to public employments, functions and honours, or the exercise of professions and industries.

No restriction shall be imposed on the free use by any Czecho- 
Slovak national of any language in private intercourse, in commerce, in religion, in the press or publications of any kind, or at public meetings.

Notwithstanding any establishment by the Czecho-Slovak Government of an official language, adequate facilties shall be given to Czecho-Slovak nationals of non-Czech speech for the use of their language, either orally or in writing, before the courts.

\section{ARTICLE 8}

Czecho-Slovak nationals who belong to racial, religious or linguistic minorities shall enjoy the same treatment and security in law and in fact as the other Czecho-Slovak nationals. In particular they shall have an equal right to establish, manage and control at their own expense charitable, religious and social institutions, schools, and other educational establishments, with the right to use their own language and to exercise their religion freely therein.

\section{ARTICLE 9}

Czecho-Slovakia will provide in the public educational system in towns and districts in which a considerable proportion of CzechoSlovak nationals of other than $\mathrm{Czech}$ speech are residents adequate facilities for ensuring that the instruction shall be given to the children of such Czecho-Slovak nationals through the medium of their 
own language. This provision shall not prevent the Czecho-Slovak Government from making the teaching of the Czech language obligatory.

In towns and districts where there is a considerable proportion of Czech-Slovak nationals belonging to racial, religious or linguistic minorities, these minorities shall be assured an equitable share in the enjoyment and application of the sums which may be provided out of public funds under the State, municipal or other budget, for educational, religious or charitable purposes.

\section{CHAPTER II}

\section{ARTICLE 10}

Czecho-Slovakia undertakes to constitute the Ruthene territory south of the Carpathians within frontiers delimited by the Principal Allied and Associated Powers as an autonomous unit within the Czech-Slovak State, and to accord to it the fullest degree of selfgovernment compatible with the unity of the Czecho-Slovak State.

\section{ARTICLE 11}

The Ruthene territory south of the Carpathians shall possess a special Diet. This Diet shall have powers of legislation in all linguistic, scholastic and religious questions, in matters of local 
administration, and in other questions which the laws of the CzechSlovak State may assign to it. The Governor of the Ruthene territory shall be appointed by the President of the Czecho-Slovak Republic and shall be responsible to the Ruthene Diet.

\section{ARTICLE 12}

Czecho-Slovakia agrees that officials in the Ruthene territory will be chosen as far as possible from the inhabitants of this territory.

\section{ARTICLE 13}

Czecho-Slovakia guarantees to the Ruthene territory equitable representation in the legislative assembly of the Czecho-Slovak Republic, to which Assembly it will send deputies elected according to the constitution of the Czecho-Slovak Republic. These deputies will not, however, have the right of voting in the Czecho-Slovak Diet upon legislative questions of the same kind as those assigned to the Ruthene Diet.

\section{ARTICLE 14}

Czecho-Slovakia agrees that the stipulations of Chapters I and II so far as they affect persons belonging to racial, religious or linguistic minorities constitute obligations of international 
concern and shall be placed under the guarantee of the League of Nations. They shall not be modified without the assent of a majority of the Council of the League of Nations. The United States, the British Empire, France, Italy and Japan hereby agree not to withhold their assent from any modification in these Articles which is in due form assented to by a majority of the Council of the League of Nations.

Czecho-Slovakia agrees that any Member of the Council of the League of Nations shall have the right to bring to the attention of the Council any infraction, or any danger of infraction, of any of the se obligations, and that the Council may the reupon take such action and give such direction as it may deem proper and effective in the circumstances.

Czecho-Slovakia further agrees that any difference of opinion as to questions of law or fact arising out of the se Articles between the Czecho-Slovak Government and any one of the Principal Allied and Associated Powers or any other Power, a Member of the Council of the League of Nations, shall be held to be a dispute of an international character under Article 14 of the Covenant of the League of Nations. The Czecho-Slovak Government hereby consents that any such dispute shall, if the other party hereto demands, be referred to the Permanent Court of International Justice. The decision of the Permanent Court shall be final and shall have the 
same force and effect as an award under Article 13 of the Covenant. 


\section{APPENDIX G \\ CZECHO-SLOVAK LANGUAGE LAW OF FEBRUARY 29, 1920\%}

1. 'The Czecho-Slovak language is the state (official) language of the Republic.' This clause of course represents a legal fiction, since the re is no such thing as a Czecho-Slovak language, but only two intimately related dialects, enjoying full parity in the administration, justice and education. As, however, the name 'Czecho-Slovak' had won general recognition and already stood as the symbol of unity, it appears to have been felt that to refer to the 'Czech and Slovak language' or 'languages' would have been not only a contradiction in terms, but actually a step away from fusion.

2. In districts containing a racial minority of at least 20 per cent, the authorities are bound to transact business with any of its members in their own language, and to is sue all proclamations and official notices in the language of the minority as well as in CzechoSlovak. The Public Prosecutor is bound to bring his indictment in the language of the accused.

*H. W. V. Temperley, ed., A History of the Peace Conference of Paris, 6 Vol., (London: Institute of International Affairs, 1921), Vol. 5, p. 470. 
3. The authorities are everywhere bound to accept oral and written communications in the Czecho-Slovak language and to sanction its use at any meeting: in other languages, only where these are spoken by 20 per cent of the population of the particular district.

4. Czech and Slovak are treated as alternative.

5. The mother-tongue is to be the language of instruction in all minority schools.

6. Linguistic provisions for Carpatho-Ruthenia are provisional, until its provincial Diet can meet and decide the question.

7. Linguistic disputes are to be decided as ordinary matters of administrative inquiry.

8. Practical executive details are to be issued by decree. 